THE DEMAND FOR COCAINE BY

YOUNG ADULTS: A RATIONAL

ADDICTION APPROACH

Michael Grossman

Frank J. Chaloupka

Charles C. Brown

Working Paper 5713

NATIONAL BUREAU OF ECONOMIC RESEARCH

1050 Massachusetts Avenue

Cambridge, MA 02138

August 1996

This paper is part of NBER's research program in Health Economics. Any opinions expressed are those of the authors and not those of the National Bureau of Economic Research.

(C) 1996 by Michael Grossman, Frank J. Chaloupka and Charles C. Brown. All rights reserved. Short sections of text, not to exceed two paragraphs, may be quoted without explicit permission provided that full credit, including $(\odot$ notice, is given to the source. 


\title{
THE DEMAND FOR COCAINE BY \\ YOUNG ADULTS: A RATIONAL \\ ADDICTION APPROACH
}

\begin{abstract}
This paper applies the rational addiction model, which emphasizes the interdependency of past, current, and future consumption of an addictive good, to the demand for cocaine by young adults in the Monitoring the Future Panel. The price of cocaine is added to this survey from the System to Retrieve Information from Drug Evidence (STRIDE) maintained by the Drug Enforcement Administration of the U.S. Department of Justice. Results suggest that annual participation and frequency of use given participation are negatively related to the price of cocaine. In addition current participation is positively related to past and future participation, and current frequency of use given participation is positively related to past and future frequency of use. The long-run price elasticity of total consumption (participation multiplied by frequency given participation) of -1.18 is substantial. A permanent 10 percent reduction in price due, for example, to the legalization of cocaine would cause the number of cocaine users to grow by slightly more than 8 percent and would increase the frequency of use among users by a little more than 3 percent. Surely, both proponents and opponents of drug legalization should take account of this increase in consumption in debating their respective positions.
\end{abstract}

Michael Grossman

Ph.D Program in Economics

City University of New York Graduate School

33 West 42nd Street

New York, NY 10036

and NBER

MGROSSMA@EMAIL.GC.CUNY.EDU
Frank J. Chaloupka

Department of Economics

University of Illinois at Chicago

601 South Morgan Street

Chicago, IL 60680

and NBER

FJC@UIC.EDU

Charles C. Brown

Department of Economics

University of Michigan

Ann Arbor, MI 48109

and NBER

CHARLIEB@UMICH.EDU 
The period from the late 1980s to the present has witnessed a lively debate concerning the costs and benefits of legalization of such substances as cocaine, marijuana, and heroin.

Legalization of these harmfully addictive goods surely will reduce their prices. ${ }^{1}$ By the law of the downward-sloping demand function, their consumption will rise. Prices will also fall and consumption will rise if these substances remain illegal, but resources allocated to enforcement activities are permanently lowered. But by how much will consumption rise? According to conventional wisdom, which is adopted by some proponents of legalization, the consumption of these illegal addictive substances is not very responsive to price. Opponents of legalization argue that consumption may be quite responsive to price based in part on research on the demand for two widely used legal addictive substances--alcohol and cigarettes--particularly by teenagers and young adults. $^{2}$

The conventional wisdom that the demand for addictive substances is not sensitive to price also is contradicted by Becker and Murphy's (1988) theoretical model of addictive behavior which assumes that addicts behave rationally. The main element of this and other models of addictive behavior is that an increase in past consumption of an addictive good raises the marginal utility of current consumption and therefore raises current consumption. A key feature of the Becker-Murphy model which distinguishes it from other models of addictive behavior is that addicts are rational or farsighted in the sense that they anticipate the expected future consequences of their current actions. This is in sharp contrast to myopic models of addiction in which consumers ignore the effects of current consumption on future utility when they determine the optimal or utility-maximizing quantity of an addictive good in the present period.

The Becker-Murphy model predicts intertemporal complementarity of consumption or negative cross price effects and a long-run own price elasticity of demand which exceeds the 
short-run elasticity (the former allows past consumption to vary while the latter does not). Intertemporal complementarity arises because increases in past or future consumption (caused by reductions in past or future prices) cause current consumption to rise. Put differently, the reinforcement property of an addictive good, which is emphasized by psychologists, suggests that an increase in past consumption raises the marginal benefit of current consumption. By symmetry, an increase in future consumption also raises the marginal benefit of current consumption. Reinforcement produces the gap between the long-run and short-run price elasticities. Since this property does not hold for a non-addictive good, the long-run price elasticity of demand is expected to be larger for addictive than for non-addictive goods.

The purpose of this paper is to inform the debate on legalization by providing estimates of the price elasticity of demand for cocaine consumption in the context of the rational addiction model. These estimates also are useful in evaluating policies such as crop reduction and criminal justice that raise price. There are few previous empirical studies in this area, and no previous attempts to study the demand for illegal drugs with a panel of individuals in the context of rational addiction because data on prices and quantities consumed of illegal drugs have been difficult to acquire. The data employed in this study consist of the panel formed from the nationally representative cross-sectional surveys of high school seniors conducted each year since 1975 by the Institute for Social Research of the University of Michigan as part of the Monitoring the Future research program. The members of the panel range in age from seventeen through twentynine. Since the prevalence of cocaine consumption is highest in this age range, and few people initiate use after age twenty-nine (National Institute on Drug Abuse 1991), information on the responsiveness to price in this segment of the population is crucial in evaluating the impacts of 
alternative price policies in all segments of the population. The price of cocaine is taken from the System to Retrieve Information from Drug Evidence (STRIDE) database maintained by the Drug Enforcement Administration of the U.S. Department of Justice.

We find that cocaine consumption by young adults is addictive in the sense that increases in past or future consumption cause current consumption to rise. The positive and significant future consumption effect is consistent with the hypothesis of rational addiction and inconsistent with the hypothesis of myopic addiction. The long-run price elasticity of -1.18 is substantial and approximately 70 percent larger than the short-run price elasticity.

\section{Prior Studies}

Prior to the 1990s, there were very few studies on the effects of price on the use of cocaine, marijuana, heroin, or other illegal drugs. Nisbet and Vakil (1972) report a price elasticity of demand for marijuana ranging from -0.36 to -1.51 in an anonymous mail survey of students at the University of California at Los Angeles. Silverman and Sprull (1977) estimate the price elasticity of demand for heroin in an indirect manner from the relationship between crime and the price of heroin in a monthly time series of forty-one neighborhoods in Detroit. They obtain an elasticity of -0.27 .

DiNardo (1993) studies the effect of cocaine price on cocaine use in the past month using the 1977-1987 Monitoring the Future high school senior surveys. Our panels are formed from these baseline surveys. DiNardo did not have access to the individual data, and his results are based on aggregations to the state level. Thus, his outcome is the fraction of high school seniors in a state who used cocaine in the past month in a time series of state cross sections. This 
outcome is not sensitive to the price of cocaine. van Ours (1995) examines the demand for opium in Indonesia from 1923 through 1938, and Liu, Liu, and Chow (1996) perform a similar analysis of the demand for opium in Taiwan from 1914 through 1942. By allowing present consumption to depend on past consumption, these two studies are the only ones to explicitly allow for addiction. van Ours obtains a substantial long-run elasticity of -1.00 , which is approximately 40 percent larger than the short-run price elasticity. He also estimates an elasticity of the annual number of opium users with respect to price that ranges from -.30 to -.40 Liu, Liu, and Chow also obtain a substantial long-run elasticity of -1.22 , which is over 300 percent larger than the short-run elasticity. Neither study finds evidence of rational addiction because the coefficient of future consumption is not significant when this variable is included in the demand functions. ${ }^{3}$

Saffer and Chaloupka (1996) consider monthly and annual cocaine and heroin participation (use in the past month or use in the past year) as outcomes in the 1988, 1990, and 1991 National Household Surveys of Drug Abuse conducted by the National Institute of Drug Abuse. The past year cocaine participation elasticity with respect to its price is -0.44 , and the corresponding elasticity for heroin is -0.82 . The price elasticities for participation in the past month are -0.28 in the case of cocaine and -0.94 in the case of heroin. Using the percentage of arrestees testing positive for cocaine and heroin in the Drug Use Forecasting System and specific assumptions about the relationship between drug use and the probability of arrest, Caulkins (1996b) estimates price elasticities of demand of -2.50 for cocaine and -1.50 for heroin. Bretteville-Jensen and Sutton (1996) study the price responsiveness of heroin in a sample of 500 users in Oslo, Norway. Unlike the other studies conducted in the 1990s, they rely on self- 
reported price data. They find a price elasticity of demand of -1.23 for non-dealing users ( 66 percent of the sample) and a price elasticity of demand of -0.20 for users who are also dealers. ${ }^{4}$

Between 1973 and 1978, eleven U.S. states enacted laws that decriminalize the possession of small amounts of marijuana. Although the possession and use of this substance is not fully legal in these states, first offense possessions are civil (not criminal) offenses with small fines of typically less than $\$ 100$ for possession of less than one ounce. Thus, the enactment of these laws reduced the "full price" of marijuana, defined as the sum of the money price and the expected penalty for possession. Johnston, Bachman, and O'Malley (1981) find no effect of decriminalization on marijuana use in the 1975-1989 Monitoring the Future high school senior surveys and in the panels formed from the first two surveys. DiNardo and Lemieux (1992) report a similar finding in the time series of state cross sections formed by DiNardo (1993) from Monitoring the Future as described above. Theius and Register (1993) replicate this result in the National Longitudinal Survey of Youth. On the other hand, Model (1993) finds that decriminalization increased use based on hospital emergency room episodes related to marijuana in the Drug Abuse Warning Network.

The Becker-Murphy (1988) rational addiction model has been applied successfully to the demand for cigarettes by Chaloupka (1991); Keeler, Hu, Barnett, and Manning (1993); and Becker, Grossman, and Murphy (1994). It also has been applied successfully to the demand for alcohol by Grossman, Chaloupka, and Sirtalan (1996) and to the demand for gambling by Mobilia (1990). All these studies report negative and significant price effects, positive and significant past and future consumption effects, and larger long-run than short-run price elasticities 


\section{Analytical Framework}

Following Becker, Grossman, and Murphy (1994), we assume that consumers maximize a lifetime utility function given by

$$
V=\sum_{t=1}^{\infty} \beta^{t-1} U\left(Y_{t}, C_{t}, C_{t-1}, e_{t}\right)
$$

Here $Y_{t}$ is consumption of a non-addictive good at time or age $t, C_{t}$ is consumption of an addictive good (cocaine in our case) at age $t, C_{t-1}$ is cocaine consumption at age $t-1$, $e_{t}$ reflects the effects of unmeasured life cycle variables on utility, and $\beta$ is the time discount factor $\left[\beta=1 /(1+r)\right.$, where $r$ is the rate of time preference for the present.$^{5}$ An increase in lagged cocaine consumption $\left(\mathrm{C}_{\mathrm{t}-1}\right)$ lowers utility if the addiction is harmful $\left(\partial \mathrm{U} / \partial \mathrm{C}_{\mathrm{t}-1}<0\right)$, while an increase in the lagged consumption raises utility if the addiction is beneficial $\left(\partial U / \partial \mathrm{C}_{\mathrm{t}-1}>0\right)$. In this paper, presumably, the partial derivative just defined is negative, although the model simply assumes that this term is nonzero. Regardless of the nature of the addiction, an increase in past consumption must raise the marginal utility of $\mathrm{C}_{\mathrm{t}}$ in order for an increase in past consumption of C to increase current consumption.

When the utility function is quadratic and the rate of time preference for the present is equal to the market rate of interest, equation (1) generates a structural demand function for consumption of $\mathrm{C}$ of the form

$$
\mathbf{C}_{\mathbf{l}}=\theta \mathbf{C}_{\mathbf{t}-\mathbf{1}}+\beta \theta \mathbf{C}_{\mathbf{t}+\mathbf{1}}+\theta_{\mathbf{l}} \mathbf{P}_{\mathbf{t}}+\theta_{2} \mathbf{e}_{\mathbf{t}}+\theta_{3} \mathbf{e}_{\mathbf{t}+\mathbf{l}}
$$

Here $P_{t}$ is the price of $C_{t}$, and the intercept is suppressed. Since $\theta$ is positive and $\theta_{1}$ is negative, current consumption is positively related to past and future consumption $\left(\mathrm{C}_{\mathrm{t}-1}\right.$ and $\mathrm{C}_{\mathrm{t}+1}$, respectively) and negatively related to current price. In particular, $\theta$ measures the effect of an 
increase in past consumption on the marginal utility of current consumption. By symmetry, it also measures the effect of an increase in future consumption on the marginal impact of current consumption on next period's utility. The larger the value of $\theta$ the greater is the degree of reinforcement or addiction.

Equation (2) is the basis of the empirical analysis in this paper. Note that ordinary least squares estimation of the equation might lead to biased estimates of the parameters of interest. The unobserved variables that affect utility in each period are likely to be serially correlated. Even if these variables are uncorrelated, $C_{t-1}$ and $C_{t+1}$ depend on $e_{t}$ and $e_{t+1}$ through the optimizing behavior. These relationships imply that an ordinary least squares estimation of the equation might incorrectly imply that past and future consumption affect current consumption, even when the true value of $\theta$ is zero. Fortunately, the specification in equation (2) suggests a way to solve the endogeneity problem. The equation implies that current consumption is independent of past and future prices when past and future consumption are held constant; any effect of past or future prices on current consumption must come through their effects on past or future consumption. Provided that the unobservables are uncorrelated with prices in these periods, past and future prices are logical instruments for past and future consumption, since past prices directly affect past consumption, and future prices directly affect future consumption. Therefore, the empirical strategy amounts to estimating equation (2) by two-stage least squares, with past and future prices serving as instrumental variables for past and future consumption.

This strategy can be modified when measures of some of the life cycle events that affect utility and therefore partially determine $\mathrm{e}_{\mathrm{l}}$, such as marital status and unemployment, are available. If $\partial^{2} \mathrm{U} / \partial \mathrm{e}_{\mathrm{t}+1} \partial \mathrm{C}_{\mathrm{t}}$. equals zero, while $\partial^{2} \mathrm{U} / \partial \mathrm{e}_{\mathrm{t}} \partial \mathrm{C}_{\mathrm{t}}$ is nonzero, $\mathrm{C}_{\mathrm{t}}$ depends on $\mathrm{e}_{\mathrm{t}}$ but not on $\mathrm{e}_{\mathrm{t}+1}$ in 
equation (2). Then current marital status, for example, is a relevant regressor in the structural demand function given by equation (2), and past and future marital status are instruments for past and future consumption.

The statistical significance of the coefficient of future consumption provides a direct test of a rational model of addiction against an alternative model in which consumers are myopic. In the latter model they fail to consider the impact of current consumption on future utility and future consumption. That is, the myopic version of equation (2) is entirely backward looking. In it current consumption depends only on current price, lagged consumption, the marginal utility of wealth (which is one of the determinants of the current price coefficient), and current events. Because of these distinctions, myopic models and rational models have different implications about responses to future changes. In particular, rational addicts increase their current consumption when future prices are expected to fall, but myopic addicts do not.

Equation (2) implies intertemporal complementarity or negative cross price elasticities between cocaine consumption at various points in time. These effects pertain to changes in the price of cocaine in period $t$ on consumption in period $t$. They are temporary in nature since prices in other periods are held constant. For example, a reduction in price in period $t-1\left(\mathrm{P}_{t-1}\right)$ with prices in all other periods held constant will increase consumption in that period. In turn, $C_{t}$ will rise since $\theta$ is positive. Along the same lines, a reduction in $P_{t+1}$ with prices in all other periods held constant will increase $C_{t+1}$, which will increase $C_{t}$ since $\beta \theta$ is positive.

Equation (2) also implies that there are important differences between long- and short-run responses to permanent price changes (price changes in more than one period) in the case of addiction. The short-run price effect describes the response to a change in price in period $t$ and all 
future periods that is not anticipated until period $t$. The long-run price effect pertains to a price change in all periods. Since $\mathrm{C}_{\mathrm{t}-1}$ remains the same if a price change is not anticipated until period $t$, the long-run price effect must exceed the short-run price effect.

These results can be seen more formally by solving the second-order difference equation in (2). The solution, which is contained in Becker, Grossman, and Murphy (1994), results in an equation in which consumption in period $\mathrm{t}$ depends on prices and life-cycle variables in all periods. The roots of this difference equation are

$$
\phi_{1}=\left[1-\left(1-4 \theta^{2} \beta\right)^{1 / 2}\right] / 2 \theta, \phi_{2}=\left[1+\left(1-4 \theta^{2} \beta\right)^{1 / 2}\right] / 2 \theta,
$$

with $4 \theta^{2} \beta<1, \phi_{1}<1$, and $\phi_{2}>1$ all for stability. Given these roots, the temporary current, past, and future price effects are

$$
\begin{aligned}
& \partial \mathbf{C}_{\mathrm{t}} / \partial \mathbf{P}_{\mathrm{t}}=\theta_{1} / \theta \phi_{2} \\
& \partial \mathbf{C}_{\mathrm{t}} / \partial \mathbf{P}_{\mathrm{t}-1}=\theta_{1} / \theta\left(\phi_{2}\right)^{2} \\
& \partial \mathbf{C}_{\mathrm{t}} / \partial \mathbf{P}_{\mathrm{t}+1}=\theta_{1} \phi_{\mathrm{l}} / \theta \phi_{2} .
\end{aligned}
$$

All are negative since $\theta_{1}$ is negative. The short-run price effect is

$$
\partial \mathrm{C}_{1} / \partial \mathrm{P}=\theta_{1} /\left[\theta\left(1-\phi_{1}\right) \phi_{2}\right]
$$

while the long-run price effect is

$$
\mathrm{dC} / \mathrm{dP}=\theta_{1} /\left[\theta\left(1-\phi_{1}\right)\left(\phi_{2}-1\right)\right]=\theta_{1} /(1-\theta-\beta \theta) .
$$

The ratio of equation (6) to equation (5) equals $\phi_{2} /\left(\phi_{2}-1\right)$. This ratio must exceed 1 since $\phi_{2}$ exceeds 1.

\section{Data and Empirical Implementation}

\section{A. Sample}


Each year since 1975 the University of Michigan's Institute for Social Research has conducted a nationally representative random sample of between 15,000 and 19,000 high school seniors during the months of March and April as part of the Monitoring the Future research program. These surveys, which are described in detail by Johnston, O'Malley, and Bachman (1994), focus on the use of illegal drugs, alcohol, and cigarettes. Starting with the class of 1976, a sample of approximately 2,400 individuals in each senior class has been chosen for followup. Individuals reporting current daily marijuana use or use of any other illegal drugs in the past 30 days in their senior year are selected with a higher probability (by a factor of 3 ). The 2,400 selected respondents are divided into two groups of 1,200 each; one group is surveyed in evennumbered calendar years, while the other group is surveyed in odd-numbered calendar years. As a result of this design, one group of panels (termed the A panels from now on) is resurveyed for the first time one year after baseline (the senior year in high school), while the other group (termed the B panels from now on) is resurveyed for the first time two years after baseline Subsequent followups are conducted at two year intervals for both groups.

We estimate cocaine demand functions using the nineteen panels formed from the high school senior surveys conducted from 1976 through $1985 .{ }^{6}$ The last followup in our data set, which contains approximately 22,800 persons, took place in 1989 . We have between one and five observations on each person since we require information on current, past, and future consumption of cocaine. For example, the first observation on a given person pertains to the first followup (which could have taken place from 1978 through 1987) with past consumption of cocaine taken from baseline (1976 through 1985) and future consumption taken from the second followup (1980 through 1989). The last observation pertains to the next to the last followup 
(1986 or 1987) with past consumption taken from the second to the last followup or from baseline (1984 or 1985) and future consumption taken from the last followup (1988 or 1989). Since an annual measure of consumption is used in the regressions, past consumption coincides with the second annual lag and future consumption coincides with the second annual lead. ${ }^{7}$ For the A panels, we have five observations for persons from the 1977 and 1978 baselines, four observations for the 1979 and 1980 baselines, three for the 1981 and 1982 baselines, two for the 1983 and 1984 baselines, and one for the 1985 baseline. For the B panels, we have five observations for persons from the 1976 and 1977 baselines, four observations for the 1978 and 1979 baselines, three for the 1980 and 1981 baselines, two for the 1982 and 1983 baselines, and one for the 1984 and 1985 baselines.

Although Monitoring the Future obtains information on the use of a variety of illegal drugs, we limit the empirical analysis to cocaine for several reasons. Cocaine prices (described in more detail in Section III.B) are available for many more areas and are based on much larger samples than the prices of other illegal drugs. Moreover, cocaine was the second most widely used illegal substance next to marijuana during the sample period. While the cocaine epidemic of the late 1970s and 1980s peaked by 1986 in Monitoring the Future (Johnston, O'Malley, and Bachman 1994) and by 1985 in the National Household Surveys on Drug Abuse (National Institute on Drug Abuse 1991), ${ }^{8}$ it is not clear whether these trends represent long-term movements or cycles in the use of various illegal drugs. Some examples of cycles or new trends in other drugs follow. The number of inmates arriving at the Rikers Island Correctional Facility in New York City who are addicted to heroin increased by 23 percent from 1994 to 1995 (Purdy 1995). The number of high school seniors using marijuana in the past year rose by 40 percent 
between 1992 and 1994 in the Monitoring the Future baselines (Johnston, Bachman, and O’Malley 1995). In addition, 1995 has witnessed widespread illicit use of the stimulant Ritalin on college campuses (Leland 1995) and the sleeping pill Rohypnol in Florida (Navarro 1995). It is probable that the demand functions for these substances have similar properties to the demand function for cocaine.

One problem with the Monitoring the Future panels is that persons who dropped out of high school prior to March of their senior year are excluded. Dropouts may have different cocaine consumption patterns than persons who remain in school. Nevertheless, the Monitoring the Future sample is the longest nationally representative panel with information on cocaine consumption in the age group that has the highest rate of cocaine use.

\section{B. Cocaine Prices}

Information on county identifiers at baseline and at each followup allowed us to augment the data set with cocaine prices from the System to Retrieve Information from Drug Evidence (STRIDE) maintained by the Drug Enforcement Administration (DEA) of the U.S. Department of Justice. DEA and FBI agents and state and local police narcotics officers purchase illicit drugs on a regular basis in order to apprehend dealers. Taubman (1991) argues that DEA agents must make transactions at close to the street price of cocaine in order to make an arrest. because an atypical price can cause suspicion on the part of dealers.

Information on the date and city of the purchase, its total cost, total weight in grams, and

purity (as a percentage) is recorded in STRIDE ${ }^{9}$ There are 139 cities in STRIDE with usable data for the period from 1977 through 1991. Following DiNardo (1993), Caulkins (1994), and 
Saffer and Chaloupka (1996), we obtained the price of one gram of pure cocaine by year and city from a regression of the natural logarithm of the total purchase cost on the natural logarithm of weight, the natural logarithm of purity, dichotomous variables for each city and year except one, and interactions between the year variables and dichotomous variables for eight of the nine Census of Population divisions. ${ }^{10}$ The regression is based on over 25,000 purchases. Since purchasers are likely to have imperfect information about purity, we treat it as endogenous and predict it based on the other regressors just mentioned. To identify the model, the coefficient of the natural logarithm of predicted purity is constrained to equal the coefficient of the natural logarithm of weight. The price of one gram of pure cocaine is then given as the antilogarithm of the sum of the intercept, the relevant city coefficient, and the relevant time-division coefficient. The money price is converted to a real price by dividing it by the annual Consumer Price Index for the U.S. as a whole $(1982-1984=1) .{ }^{11}$

Several things should be noted about the methodology just described. First, it eliminates variations in the price or unit cost of cocaine due to variations in weight and purity. Second, the resulting year- and city-specific price is akin to a geometric mean. Hence, the influence of outliers is mitigated. Finally, we experimented with alternative specifications of the total cost regression In one specification, interactions between time and Census division were eliminated. In a second, purity was treated as exogenous with an unconstrained coefficient. In a third, purity was deleted as a regressor, but its predicted value was included as an independent variable in the cocaine demand function. The estimates presented in Section IV are not sensitive to these alternative specifications of the total cost regression. 
To match DEA cities to Monitoring the Future counties, we assigned each to its Metropolitan Statistical Area, Central Metropolitan Statistical Area, or Primary Metropolitan Statistical Area (whichever was smaller). For any county where a match could not be made, price was defined as a population-weighted average of price in all DEA cities in that county's state. ${ }^{12}$ The second annual lag and the second annual lead of the real price of cocaine, which are employed as instruments in two-stage least squares regression models, were added to the panels in the same manner. ${ }^{13}$ Changes of residence to a different county by panel members during the sample period were taken into account when the prices were added.

Although our sample period includes the widespread introduction of crack cocaine in late 1985 or early 1986, we do not distinguish between the price of crack and the price of powder cocaine. Crack's reputation for being less expensive than powder is due primarily to the smaller quantity at which it is retailed (Caulkins 1995). Caulkins (1996a) finds that the price per pure gram of crack is the same as the price per pure gram of powder cocaine. Crack cocaine gives a more intense but shorter high than powder cocaine. If quantity is defined as the product of intensity and duration, it is not clear which type of cocaine is more or less expensive.

The national trend in our measure of the real price of one gram of pure cocaine from 1978 through 1994 is depicted in Figure 1. Prices in the last three years are based on the assumption that the trend in our series is the same as the trend in the series constructed by Rhodes and Pittayathikhun (1996). The current price in our empirical analysis fell by 78 percent in the sample period of 1978 through 1987 which is used to fit the demand functions in Section IV. ${ }^{14}$ Similar declines have been found and discussed in detail by Kleiman (1992); Caulkins and Padman (1993); Caulkins (1994); and Rhodes, Hyatt, and Scheiman (1994). One factor was the development of 
the production sector and the results of learning-by-doing that followed the reintroduction of cocaine into the U.S. market in the early 1970s after a long period of absence (see below for more details). A second was vertical integration, which reduced the number of levels in the chain of distribution and the cost of wholesaling and retailing. Finally, there was a shift to low-cost labor as the professionals who dealt cocaine in the 1970 s were replaced by unemployed residents of urban ghettos in the 1980s. ${ }^{15}$

The full price of consuming cocaine consists of three components: (1) the money price; (2) the monetary value of the travel and waiting time required to obtain cocaine; and (3) the monetary value of the expected penalties for possession or use (the probability of apprehension and conviction multiplied by the fine or the monetary value of the prison sentence). We assume that variations in cocaine prices among cities can be used to trace out a demand function because they reflect differences in the three components of the full price among cities. Put differently, larger transportation costs, stiffer fines and prison terms imposed on dealers, and higher probabilities of apprehension and conviction cause the supply function of cocaine to shift upward and raise the money price of cocaine. To the extent that the number of dealers in the market falls, travel and waiting costs also rise. The full price will also increase if the expected penalty for possession and use is positively related to the expected penalty for selling cocaine. ${ }^{16}$ Since the direct and indirect price of obtaining cocaine are likely to be positively correlated, consumers may respond to changes in money prices even if they have imperfect knowledge about these prices.

In order to support the above assumptions, we present some evidence based on an analysis of variations in the price of cocaine among DEA cities for the year 1991. For that year, statespecific measures of the penalties for the possession and for the manufacture, delivery, or sale of 
cocaine are available from the National Criminal Justice Association (1991). These variables reflect the statutory minimum and maximum dollar fines and prison terms for first offense cocaine possession and sale. The correlation and regression results summarized below use the midpoints of the minimum and maximum fines and prison terms, but similar results were obtained with the minimums or the maximums. We also included four positive correlates of the probability of apprehension and conviction [police employment per capita, police expenditures per capita, criminal justice employment per capita, and criminal justice expenditures per capita, all measured at the state level and obtained from the Bureau of Justice Statistics (1992)] and one negative correlate (the population of each city). Ehrlich (1973) argues that offenders find it relatively easier to elude the police in densely populated areas. Population size also may reflect the development of the cocaine market and the cost of distribution in different cities. Finally, we identified eight cities that serve as ports of entry for cocaine from the DEA Intelligence Division (various years): New York, Miami, Los Angeles, Houston, San Diego, New Orleans, Dallas, and Phoenix. Due to the costs of shipping cocaine to other cities, prices should be lower in ports of entry.

The results of the correlation and regression analysis are summarized below. Tables and a more complete analysis are available upon request. The results should be interpreted with caution for a variety of reasons. First, the fines and prison terms are measured at the state level rather than at the county level. Moreover, statutory penalties may be weakly related to penalties that are actually imposed. Resources allocated to law enforcement may be high in cities and states with large cocaine markets and low prices. Finally, many of the variables are highly correlated and 
cannot be included in the same regressions. With these caveats in mind, findings emerge that justify our interpretation of the sources of price variation among areas.

(1). The prison term for cocaine sale is highly correlated with the prison term for cocaine possession $(r=0.83)$. Similarly, the dollar fine for sale is highly correlated with the dollar fine for possession $(r=0.56)$

(2). The simple correlation coefficient between the real price of cocaine and the prison term for cocaine sale and between the price and the fine for sale are positive and statistically significant $(r=0.19$ and $r=0.17$, respectively). The penalty measures retain their positive signs, although not always their significance, in the multiple regressions.

(3). Regardless of the other variables that are held constant, the relationship between price and population is negative and significant. Price is lower in the eight port of entry cities than in other cities with differentials ranging from approximately $\$ 6$ in the case of New Orleans to $\$ 38$ in the case of Miami.

(4). With population held constant, three of the four law enforcement measures are positively related to price, and the positive coefficient of police employment is significant. The exception pertains to criminal justice expenditures per capita.

\section{Measurement of Variables}

Table 1 contains definitions, means, and standard deviations of variables that are employed in the regression analyses in Section IV. They are based on the sample of 38,885 person-years or person-followups that results by deleting persons who failed to respond to at least three consecutive questionnaires (including baseline) and by deleting observations for which the use of 
cocaine in the past year, the real price of cocaine, and real annual earnings are missing. Given three observations per person on average, there are approximately 12,962 respondents in the final sample.

There are no missing values for age, male, black, and other race/etnnicity. Missing values for the other variables listed in the table are replaced by panel- and strata-specific means. Recall that there are two strata for each panel. One consists of persons who used marijuana daily at baseline or used another illegal drug during the past month at baseline, and the other consists of persons who did not exhibit these illegal drug use patterns at baseline. The means and standard deviations in the table are weighted to correct for oversampling--by a factor of three--of persons in the illegal drug stratum. In particular, they are weighted by the inverse of the probability of selection, which is equivalent to multiplying values of a given variable from the illegal drug stratum by one-third. Thus, the means and standard deviations in the table are representative of those in the population.

Panel members report the number of occasions in the past year on which they used cocaine. This is an ordered categorical variable with 7 outcomes: 0 occasions, 1-2 occasions, 3-5 occasions, 6-9 occasions, 10-19 occasions, 20-39 occasions, and 40 or more occasions. Since many persons did not use cocaine in the past year, two dependent variables are considered. One is a dichotomous variable that identifies users (termed cocaine participation), and the second gives frequency of use (number of occasions) conditional on positive participation. Cocaine participation has a weighted mean of 15.9 percent. Since the unweighted mean is 23.0 percent, the sample of positive users contains 8,926 observations (person-years). Cocaine frequency is 
converted into a continuous variable by assigning midpoints to the closed intervals and a value of 50 to the open-ended interval.

Monitoring the Future did not distinguish between the use of crack cocaine and the use of other forms of cocaine until the 1986 baseline survey (not included in our sample) and the 1987 followup survey. In that followup and in the 1988 and 1989 followups, two-fifths of the respondents were asked separate questions on crack and powder cocaine. These answers have been aggregated to form indicators of the use of any form of cocaine and the frequency of use by means of an algorithm developed by the Institute for Social Research.

To account for the possibility that cocaine and alcohol or cocaine and marijuana are substitutes or complements, we include the minimum legal drinking age for the purchase and consumption of low-alcohol beer and a dichotomous variable that identifies respondents of states that have decriminalized the possession of marijuana. ${ }^{17}$ Since no state has ever had a legal drinking age greater than twenty-one, the drinking age is multiplied by a dichotomous variable that equals one for persons twenty-one years of age or younger. In reality, since precise birth dates are not available and respondents could have changed from illegal drinkers to legal drinkers during the past year, the variable just mentioned takes the form of a dichotomous indicator for the first two followups. ${ }^{18}$

In addition to the own-state minimum legal drinking age, a dichotomous indicator equal to one if a respondent resides in a county within 25 miles of a state with a lower legal drinking age is employed as a regressor. This variable is equal to zero if the respondent does not live in a county within 25 miles of another state or if the drinking age in his or her state is as low or lower than that in nearby states. It is interacted with the dichotomous indicator for persons whose age is less 
than or equal to twenty-one for the same reason that the drinking age is interacted with this indicator. The border age variable is included in the model to capture potential border crossings by youths from states with high drinking ages to nearby lower age states to obtain alcohol. With the own-state legal drinking age held constant, the coefficient of the border age variable in the demand function should be negative if alcohol and cocaine are substitutes (the own-legal drinking age coefficient is positive in this case) and positive if they are complements.

Panel members are approximately age seventeen at baseline. The A panels, whose first followup occurs one year after baseline, are age eighteen at that followup, age twenty at the second followup, age twenty-two at the third, age twenty-four at the fourth, and age twenty-six at the fifth. The B panels, whose first followup occurs two years after baseline, are age nineteen at that followup, age twenty-one at the second followup, age twenty-three at the third, age twenty-five at the fourth, and age twenty-seven at the fifth. In the absence of precise birth dates, the five even ages in Table 1 are dichotomous variables for the first, second, third, fourth, and fifth followups, respectively, for the A panels. Similarly, the four odd ages are dichotomous variables for the first, second, third, and fourth followups, respectively, for the B panels.

In addition to the age variables just described, a variety of independent variables were constructed from the demographic and socioeconomic information collected in the surveys. These include sex; race (black or other); real annual earnings; ${ }^{19}$ years of formal schooling completed; college student status (full-time, half-time, or less than half-time); work status (fulltime, part-time, or unemployed); ${ }^{20}$ religious participation (infrequent or frequent); marital status (married, engaged, or separated or divorced); and the respondent's number of children. Finally, all models include dichotomous variables for nine of the ten years covered by current consumption 
(1978 through 1986). The time-varying variables serve as proxies for life-cycle variables that affect the marginal utility of current consumption.

\section{Estimation Issues}

Given the sharp downward trend in the real price of cocaine in Figure 1, it is worth considering trends in cocaine participation and frequency. These trends for eighteen and nineteen year olds are shown in Figure 2. They coincide with information reported in the first followup.

The unbalanced nature of the panel distorts trends if they are not shown on an age-specific basis. ${ }^{21}$ Twenty and twenty-one year olds do not enter the panel until 1980; twenty-two and twenty-three year olds do not enter until 1982; twenty-four and twenty-five year olds do not enter until 1984; and twenty-six and twenty-seven year olds do not enter until 1986. Hence, age is positively correlated with calendar time. Eighteen and nineteen year olds are present in all years for which we have observations on current consumption (1978-1987). Data in the figure for the years 1990-1994 were provided by the Institute for Social Research.

Participation rose from 11.8 percent in 1978 to 16.9 percent in 1982 . After a decline to 13.8 percent in 1983, it grew to 15.9 percent in 1986 and then fell continuously after that year. The trend in frequency is more erratic. There was an overall peak of 9.6 occasions in 1981, but the value in 1988 (9.5) was almost as large. In the sample period frequency grew between 1978 and 1981 and between 1982 and 1985, while it declined in 1986 and 1987.

How should these trends be taken into account in the regression models? One approach is to omit the time dummies and to attribute the trend in consumption to the trend in price. From a practical point of view, this amounts to omitting the age dummies as well as the time dummies. 
As indicated above, age is a positive correlate of time, and time effects are reflected by age effects if time is omitted.

A second approach is to employ the time dummies to capture unmeasured national developments that may have impacted cocaine consumption. These developments include the “just say no" to drugs campaign begun by Nancy Reagan shortly after Ronald Reagan became President in 1981, efforts by the Partnership for a Drug-Free America to publicize the harmful effects of cocaine, and the dramatic cocaine-related deaths in June 1986 of the basketball star Len Bias and the football star Don Rogers. They also include the increase in resources devoted to interdiction and criminal justice as part of the Federal War on Drugs and the introduction and diffusion of mandatory drug testing in a variety of settings.

One can argue, perhaps in hindsight, that the hazards of cocaine have been recognized for a long time. Cocaine use was fairly widespread in the U.S. from the late 1880 s until the early 1900s when many states enacted criminal prohibitions. This process culminated in a Federal ban under the 1914 Harrison Act (Musto 1973), and the drug virtually disappeared from use until the early 1970s. Apparently, so did the knowledge about the harm that it can do. In August 1974 Dr. Peter Bourne, who later served as President Jimmy Carter's science advisor, stated: "Cocaine, once a component of many tonics and of Coca-Cola, is probably the most benign of illicit drugs currently in widespread use. The number of people seeking treatment as a result of cocaine use is for all practical purposes zero (quoted by Kerr 1986, p. B6)." In the 1980 edition of the Comprehensive Textbook of Psychiatry, the main psychiatric textbook in the U.S., Dr. Lester Grinspoon and James B. Bakalar wrote: "If it is used no more than two or three times a week, cocaine creates no serious problems.... At present, chronic cocaine use does not usually appear as 
a medical problem (pp. 1621-1622)." Given these statements and the developments summarized above, our preferred specification includes the time and age dummies. We do, however, indicate how the results are altered when these variables are omitted.

We estimate separate equations for participation and for frequency given positive participation. This is an application of Cragg's (1971) model for an outcome (cocaine consumption) with many nonparticipants or zero values. We prefer it to Heckman's (1979) sample selection procedure because the latter pertains to a situation where the use of cocaine is not observed for some individuals. In our case this variable is observed and equal to zero for nonparticipants. ${ }^{22}$

Given the nature of the panels, we estimate the participation version of equation (2) with the second lag of participation as the measure of past consumption and the second lead of participation as the measure of future consumption. Similarly, we estimate the equation for frequency conditional on positive use with the second lag of frequency as the measure of past consumption and the second lead of frequency as the measure of future consumption. ${ }^{23}$ Since past consumption and future consumption are endogenous, the equation is fitted by two-stage least squares (TSLS). The instruments consist of the exogenous variables in the model, the second lag of the annual real cocaine price, the second lead of the annual real cocaine price, the second annual lag and lead of the marijuana decriminalization indicator, the second annual lags of the two measures pertaining to the legal drinking age (legal drinking age*age $\leq 21$ and lower border drinking age indicator*age $\leq 21$ ), and the second leads and the second lags of all timevarying socioeconomic variables. ${ }^{24}$ These include real annual earnings, years of formal schooling completed, college student status, work status, religious participation, marital status, and number 
of children. The second leads of the two measures pertaining to the legal drinking age are not used as instruments because the values of these two variables are zero except at the first followup. The second leads and second lags of all time-varying socioeconomic variables are valid instruments for reasons given in Section II.

At the first followup, second lags of socioeconomic variables pertain to baseline data. For this followup, the second lag of years of formal schooling completed equals 11 for all respondents, and the second lags of the full-time, half-time, and less than half-time college student status indicators all are equal to zero. The second lag of work status is taken from a baseline question on average hours of work per week during the school year. ${ }^{25}$ High school seniors who do not work at all during the school year are assumed to be not in the labor force rather than unemployed. The second lag of earnings as of the first followup equals the sum of income from work during the school year and other sources such as allowances and summer jobs. ${ }^{26}$

Linear probability models for participation and linear models for frequency given participation are obtained. The two-stage least squares participation equations correspond to Heckman and MaCurdy's (1985) simultaneous equations linear probability model. Frequently, Cragg's model is estimated by taking a logarithmic transformation of use conditional on positive use. We avoid this since the quadratic utility function, which is the most simple form in the context of addiction, generates a linear demand function.

In interpreting the estimates in Section IV, one should bear in mind that both cocaine use and price are subject to measurement error. Cocaine frequency is measured with error because of the open-ended frequency category of 40 or more occasions in the past year. Clearly, the magnitudes of the elasticities may be affected by the number of occasions assigned to this 
category. Thus, it is more important to focus on the relative magnitudes of the elasticities (the long-run relative to the short-run or relative to the temporary) than on the absolute magnitudes of the elasticities.

Cocaine use also is measured inaccurately if self-reports are subject to response error. The validity and reliability of self-reported illegal drug use data in the Michigan surveys have been examined by Johnston, O'Malley, and Bachman a number of times (for example, 1994). They conclude that the data have very high degrees of validity and reliability. In a related area, the implications of response error in self-reported alcohol use for the estimation of alcohol demand functions are considered in detail by Grossman, Coate, and Arluck (1987) and by Coate and Grossman (1988). They conclude that computed price effects are unbiased or conservative lower-bound estimates under a variety of alternative assumptions.

The real price of cocaine contains measurement error for several reasons. First, the price data pertain to the DEA survey city nearest to the respondent's county of residence rather than to the city or town in which the respondent actually resides. Second, the respondent may have imperfect information concerning the market price and the quality (purity) of the purchase, which creates a difference between this price and the perceived price that governs his or her consumption. Third, the future price employed assumes that respondents who moved fully anticipated the move. Random measurement error in an independent variable biases its coefficient and $\mathrm{t}$-ratio toward zero. Thus, the price coefficients and associated $\mathrm{t}$-ratios in Section IV are conservative lower-bound estimates. ${ }^{27}$

Despite the oversampling of illegal drug users in the past month at baseline, unweighted regressions are obtained. Maddala (1983, pp. 170-171) shows that this is the appropriate 
procedure in the case of exogenous stratification (oversampling on the basis of an exogenous variable in a regression model). In particular, if $w_{j}$ is the inverse of the sampling fraction for the jth stratum, there is no justification for a weighted least squares procedure in which $\left(\mathrm{w}_{\mathrm{j}}\right)^{1 / 2}$ is the weight. The reason is that in regression analysis weighting is employed to produce efficient estimates rather than to produce consistent estimates. There is no reason why the drawing of non-equiproportionate samples from different strata should introduce heteroscedasticity such that the residual variance is $\mathrm{s}^{2} / \mathrm{w}_{\mathrm{j}}$, where $\mathrm{s}^{2}$ is a constant.

Maddala (1983, pp.171-173) also shows that it is appropriate to weight by $\left(\mathrm{w}_{\mathrm{j}}\right)^{1 / 2}$ in the case of endogenous stratification (oversampling on the basis of the depencient variable in a regression model). In our case, the oversampling is based on a variable--illegal drug use in the past month at baseline--that does not enter the regression model as a dependent or independent variable. Perhaps an argument could be made for weighting because this variable is positively related to current annual cocaine participation or frequency. But Maddala's model assumes that slope coefficients are the same in the two strata. For large enough samples, this could be investigated by obtaining separate regressions for each stratum. ${ }^{28}$ But the stratum generated by persons who used illegal drugs at baseline does not account for a sufficient percentage of cases (person-years) to obtain reliable parameter estimates.

Our preferred strategy is to pool the two strata and fit unweighted regressions. The resulting coefficients essentially are averages for the two strata. This is the strategy suggested by DuMouchel and Duncan (1983). They show that weighted regressions are not appropriate in a stratified sample if the linear homoscedastic model is correct or if averages of strata-specific regression coefficients are desired. We did, however, experiment with weighted regressions and 
found that they were very similar to the unweighted estimates in Section IV. This statement pertains to coefficients, standard errors, and elasticities. Note that the difference between the weighted and the unweighted frequency of use in the sample of positive cocaine users is small: ( 9.20 occasions versus 10.23 occasions).

\section{Empirical Results}

Tables 2 and 3 test the rational addiction model of cocaine consumption by estimating structural demand functions given by equation (2) for cocaine participation (Table 2) and for frequency of cocaine use given positive participation (Table 3). The first two columns of each table contain two-stage least squares (TSLS) regressions in which past and future participation or past and future frequency are endogenous. In the first column the legal drinking age, the border drinking age indicator, and the marijuana decriminalization measure are omitted, while in the second column they are included. Columns three and four contain the corresponding ordinary least squares regressions. The tables also contain chi-squared statistics resulting from Hausman's (1978) test of the hypothesis that OLS estimates are consistent.

With two degrees of freedom, the critical chi-squared values are 5.99 at the 5 percent level and 9.21 at the 1 percent level. Since the computed values always are smaller than these critical values, the consistency of the OLS estimates is accepted. Nevertheless, it is useful to consider all the estimates in the two tables because they are similar and because the consistency of OLS is rejected in some of the alternative specifications discussed later.

The estimated effects of past and future participation on current participation are significantly positive in the four regressions in Table 2 , and the estimated cocaine price effects are 
significantly negative. The same comments apply to the past frequency, future frequency, and cocaine price coefficients in the four regressions in Table 3. The positive and significant past participation or past frequency coefficient is consistent with the hypothesis that cocaine consumption is an addictive good. The positive and significant future participation or future frequency coefficient is consistent with the hypothesis of rational addiction and inconsistent with the hypothesis of myopic addiction. The sum of the past and future participation or frequency coefficients is always smaller than one. This means that the long-run, short-run, and temporary price effects, which are discussed in more detail below, are negative. The stability of these results across alternative outcomes, specifications, and estimation methods is quite impressive.

Clearly, the estimates indicate that cocaine consumption is addictive in the sense that past and future changes significantly impact current consumption. The evidence is inconsistent with the hypothesis that cocaine consumers are myopic. Moreover, based on the frequency demand functions, three of the four estimates of the implied discount factor ( $\beta$ )--given by the ratio of the coefficient of future consumption to the coefficient of past consumption--are quite reasonable. The discount factor is 0.90 in the first regression in Table 3, 1.03 in the second regression, and 0.96 in the third and fourth regressions. The first discount factor corresponds to an interest rate of 11 percent, while the last two correspond to an interest rate of 4 percent. The second gives a negative interest rate of -3 percent. The same computations applied to the participation equations yield discount factors ranging from 1.19 to 1.08 and negative interest rates ranging from -16 percent to -7 percent. These results are not fully consistent with rational addiction. ${ }^{29}$

We imposed a discount factor of 0.95 (interest rate of 5 percent) a priori and reestimated the eight regressions in Tables 2 and 3. The price coefficients in these models are extremely close 
to their unconstrained counterparts. These results, combined with the detailed analysis in Becker, Grossman, and Murphy (1994) and in Grossman, Chaloupka, and Sirtalan (1996) suggest that data on cocaine, cigarette, or alcohol consumption may not be rich enough to pin down the discount factor with precision even if the rational addiction model is accepted.

Table 4 uses the estimates from Tables 2 and 3 to compute the elasticity of participation (Panel A) or the elasticity of frequency given positive participation (Panel B) with respect to the various price changes defined in Section II at the weighted sample means of price, participation, and frequency [see equations (4a-c), (5), and (6)]. Panel $\mathrm{C}$ of Table 4 contains unconditional price elasticities defined as the sum of the relevant participation and frequency elasticities. The long-run participation price elasticity is substantial. It ranges from -1.26 to -1.56 with a mean of -1.40. The short-run participation price elasticity ranges from -0.68 to -0.80 (average equals -0.73). Thus, the average long-run participation elasticity is approximately twice as large as the short-run elasticity.

Frequency conditional on positive use is not as sensitive to price as participation. The average long-run elasticity is -0.47 , and the average short-run elasticity is -0.33 . The unconditional price elasticities are quite large: -1.87 on average in the long run and -1.06 on average in the short run. The ratio of the long-run elasticity to the short-run elasticity of 1.76 should be compared to a ratio of approximately 1.91 in the case of cigarettes (Becker, Grossman and Murphy 1994) and 1.60 in the case of alcohol (Grossman, Chaloupka, and Sirtalan 1996). Becker, Grossman, and Murphy (1991) show that the ratio of the long-run price elasticity to the short-run price elasticity rises as the degree of addiction, measured by the coefficient of past consumption, rises. Hence, our results suggest that cocaine is less addictive than cigarette 
smoking but more addictive than alcohol consumption. There is no consensus in the pharmacological literature concerning the ranking in terms of addiction of these three substances. But our results are consistent with some of the evidence presented in this literature (Kozlowski, Wilkinson; Skinner, Kent, Franklin, and Pope 1989; Henningfield, Clayton, and Pollin 1990; Henningfield, Cohen, and Slade 1991).

With regard to the temporary price elasticities, a 10 percent reduction in the current price causes the number of cocaine users to increase by approximately 3.4 percent and causes the frequency of use to rise by approximately 2.4 percent. A 10 percent reduction in current price also leads to a 1.6 percent increase in participation next year and a 1.8 increase in participation last year. Finally, the frequency of use next year rises by 0.7 percent, and the frequency of use last year also rises by 0.7 percent. These negative cross price effects are inconsistent with nonaddictive behavior, and the negative future price effect is inconsistent with myopic behavior.

There is some evidence in Tables 2 and 3 that cocaine and marijuana are complements in consumption, while cocaine and alcohol are substitutes. Both cocaine participation and frequency are higher in states that decriminalized marijuana than in other states, although the frequency coefficients are not statistically significant. Another interpretation of this finding is that the expected penalty for cocaine use is smaller in states that decriminalized marijuana. An increase in the legal drinking age raises cocaine participation and use, although again the frequency effects are not significant. Although the coefficient of the lower border age drinking indicator has the wrong sign, the sign and significance of the drinking age coefficient itself are not altered when the border age measure is deleted. But the conclusion that cocaine and alcohol are substitutes must be 
tempered because states with higher drinking ages may allocate more resources to enforcement of drinking age laws and less resources to apprehending and convicting cocaine users and dealers.

The last finding we wish to note is the positive effect of real earnings on participation and frequency. Although the participation coefficients are not significant at conventional levels, the frequency coefficients all have t-ratios in excess of three. The long-run earnings elasticity of participation equals 0.11 in the four models in Table 2 , and the long-run earnings elasticity of frequency falls between 0.14 and 0.22 in the four models in Table 3 . The long-run unconditional earnings elasticity ranges from 0.25 to 0.33 .

In Table 5 we examine the sensitivity of the price and consumption effects to the omission of the time and age variables. Age is omitted because it is strongly correlated with calendar time (see Section III for more details). Since the legal drinking age has a sharp upward trend, the models that include it are not part of the sensitivity analysis.

In a qualitative sense, the results in Table 5 are consistent with those in Tables 2 and 3 The past and future consumption coefficients are positive and significant, and the current price coefficients are negative and significant. The price elasticities are, however, smaller ${ }^{30}$ Based on averages of the two models estimated, the unconditional price elasticity is -0.82 in the long run, -0.46 in the short run, and -0.26 for a temporary current price change. Each of these elasticities is approximately two-fifths as large as the corresponding elasticity in the model that control for age and time $(-1.87,-1.06$, and -0.57 , respectively $)$

In Table 6 we examine the robustness of the price and consumption effects by estimating two-stage least squares fixed-effects models. Using this technique, we transform all time-varying variables into deviations from person-specific means and delete time-invariant variables and cases 
where there is only one observation for a given person from the regression. This approach is equivalent to including a dummy variable for each person in an untransformed specification and controls for unobserved heterogeneity. ${ }^{31}$ Since the Hausman tests strongly reject the consistency of OLS, only the TSLS coefficients are presented in the table. ${ }^{32}$

On the whole, the results in Table 6 confirm those in Tables 2 and 3. The past and future consumption coefficients are positive and significant. The current price coefficients are negative, although the frequency effects are not significant. The average long-run unconditional elasticity of -0.83 is smaller than the one in Table 4 but almost exactly equal to the one in Table 5 . The average short-run and temporary price elasticities ( -0.62 and -0.42 , respectively) are bigger than those in Table 5 but smaller than those in Table 4

Which of the three sets of estimates are preferable? The specification in Table 4 is based on the questionable assumption that information about the harmful effects of cocaine was fully diffused at the beginning of our sample period (1978) and that the various anti-drug campaigns in the 1980 s had no impact on the use of cocaine. As pointed out in Section III.D, the real price of cocaine contains random measurement error for a variety of reasons. The downward biases in the price coefficient and its t-ratio due to this factor are exacerbated in the fixed-effects model in Table 6 (Griliches 1979; Griliches and Hausman 1986). Thus the estimates in Tables 5 and 6 are not necessarily superior to those in Tables 2 and 3. Taken together, however, the four tables underscore the stability and validity of our findings. Despite our misgivings about the fixed effects model and the model that ignores time trends, we summarize the magnitudes of the price elasticities by averaging over the three models. This gives a long-run unconditional price elasticity of -1.18 , a short-run price elasticity of -0.71 , and a temporary current price elasticity of 
-0.42 . We view these figures as conservative lower-bound estimates.

\section{Discussion}

We find that cocaine consumption is quite sensitive to its price. A permanent 10 percent reduction in price would cause the number of cocaine users to grow by slightly more than 8 percent in the long run and would increase the frequency of use among users by a little more than 3 percent. Total or unconditional frequency would rise by almost 12 percent in a fixed population in the long run and by almost 7 percent in the short run. Surely, both proponents and opponents of drug legalization should take account of this increase in consumption in debating their respective positions.

A good deal of caution, however, must be exercised in extrapolating our findings to a regime in which cocaine consumption is legal. One consideration is that the response to the large price cut caused by legalization would be smaller than the one suggested by our estimates if the price elasticity of demand is smaller at lower prices. A second consideration is that government tax policies could counteract part of the price cut, and government education policies could be used to increase knowledge about the harmful effects of cocaine consumption. A third factor is that "forbidden fruit is attractive, particularly to the young (Friedman 1989, p. A16)." A factor that goes in the opposite direction is that legalization may stimulate consumption by removing the stigma associated with cocaine consumption.

A misleading impression about the reaction to permanent price changes may have been created by the effects of temporary police crackdowns on drugs or temporary federal "wars" on drugs. Since temporary policies raise current but not future prices (they would even lower future 
prices if drug inventories are built up during the crackdown period), there is no complementary fall in current use from a fall in future use. Consequently, even if drug addicts are rational, a temporary war that greatly raised the street price of cocaine may well only have a small effect on drug use, whereas a permanent war could have much bigger effects. For example, according to our estimates, a 10 percent price hike for one year would reduce total cocaine consumption by approximately 4 percent, whereas a permanent 10 percent price hike would lower consumption by 12 percent.

Clearly, we have not provided enough evidence to evaluate whether or not the use of cocaine should be legalized. A cost-benefit analysis of many effects is needed to decide between a regime in which cocaine is legal and a regime in which it is not. What we have shown is that the permanent reduction in price caused by legalization is likely to have a substantial positive effect on use, particularly among young adults. 


\section{REFERENCES}

American Chamber of Commerce Researchers Association. Inter-City Cost of Living Index. Louisville, Kentucky: American Chamber of Commerce Researchers Association, various years.

Becker, Gary S.; Grossman, Michael; and Murphy, Kevin M. "An Empirical Analysis of Cigarette Addiction." American Economic Review, 84, No. 3 (June 1994), 396-418.

Becker, Gary S.; Grossman, Michael; and Murphy, Kevin M. "Rational Addiction and the Effect of Price on Consumption." American Economic Review, 81, No. 2 (May 1991), 237-241

Becker, Gary S., and Murphy, Kevin M. “A Theory of Rational Addiction.” Journal of Political Economy, 96, No. 4 (August 1988), 675-700.

Bretteville-Jensen, Anne Line, and Sutton, Matthew. "Under the Influence of the Market: An Applied Study of Illicitly Selling and Consuming Heroin." Discussion Paper 147, University of York Centre for Health Economics, March 1996.

Bureau of Justice Statistics, U.S. Department of Justice. Sourcebook of Criminal Justice Statistics, 1991. Washington, D.C.: U.S. Government Printing Office, 1992.

Caulkins, Jonathan P. "Is Crack Cheaper than (Powder) Cocaine?" Working Paper, Carnegie Mellon University, May 1996a.

Caulkins, Jonathan P. "Developing Price Series for Cocaine." Santa Monica, California: Rand Corporation, 1994.

Caulkins, Jonathan P. "Domestic Geographic Variation in Illicit Drug Prices." Journal of Urban Economics, 37, No. 1 (January 1995), 38-56. 
Caulkins, Jonathan P. "Estimating Elasticities of Demand for Cocaine and Heroin with DUF Data." Working Paper, Carnegie Mellon University, April 1996b.

Caulkins, Jonathan P., and Padman, Rema. "Quantity Discounts and Quality Premia for Illicit Drugs." Journal of the American Statistical Association, 88, No. 423 (September 1993), 748-757.

Chaloupka, Frank J. "Rational Addictive Behavior and Cigarette Smoking." Journal of Political Economy, 99, No. 4 (August 1991), 722-742.

Chaloupka, Frank J., and Laixuthai, Adit. "Do Youths Substitute Alcohol and Marijuana? Some Econometric Evidence.” National Bureau of Economic Research Working Paper No. 4662, February 1994.

Chaloupka, Frank J.; Saffer, Henry; and Grossman, Michael. "Alcohol-Control Policies and Motor-Vehicle Fatalities." Journal of Legal Studies, 22, No. 1 (January 1993), 161-186.

Coate, Douglas, and Grossman, Michael. "Effects of Alcoholic Beverage Prices and Legal Drinking Ages on Youth Alcohol Use." Journal of Law and Economics, 31, No. 1 (April 1988), $145-171$.

Cragg, John G. "Some Statistical Models for Limited Dependent Variables with Application to the Demand for Durable Goods." Econometrica, 39, No. 5 (September 1971), 829-844.

DiNardo, John. "Law Enforcement, the Price of Cocaine, and Cocaine Use." Mathematical and Computer Modeling, 17, No. 2 (1993), 53-64.

DiNardo, John, and Lemieux, Thomas. "Alcohol, Marijuana, and American Youth: The Unintended Effects of Government Regulation." National Bureau of Economic Research Working Paper No. 4212, November 1992. 
DuMouchel, William H., and Duncan, Greg J. "Using Sample Survey Weights in Multiple Regression Analyses of Stratified Samples." Journal of the American Statistical Association, 78, No. 383 (September 1983), 535-543.

Drug Enforcement Administration Intelligence Division, U.S. Department of Justice. Illegal Drug Price/Purity Report. Washington, D.C. : U.S. Department of Justice, various years. Ehrlich, Isaac. "Participation in Illegitimate Activities: A Theoretical and Empirical Investigation." Journal of Political Economy, 81, No. 3 (May/June 1973), 521-565. Frank, Richard S. "Drugs of Abuse: Data Collection Systems of DEA and Recent Trends." Journal of Analytical Toxicology, 11, No. 4 (1987), 237-241.

Friedman, Milton. "An Open Letter to Bill Bennett." Wall Street Journal, September 7, 1989, A16

Griliches, Zvi. "Sibling Models and Data in Economics: Beginnings of a Survey." Journal of Political Economy, 87, No. 5, Part 2 (October 1979), S37-S64.

Griliches, Zvi, and Hausman, Jerry A. "Errors in Variables in Panel Data." Journal of Econometrics, 31, No. 1 (February 1986), 93-118.

Grinspoon, Lester, and Bakalar, James B. "Drug Dependence: Nonnarcotic Agents." In Comprehensive Textbook of Psychiatry, Volume 2, Third Edition, edited by Harold I. Kaplan, Alfred M. Freedman, and Benjamin J. Sadock. Baltimore, Maryland: Williams and Wilkins, 1980, 1614-1629.

Grossman, Michael. "The Economic Analysis of Addictive Behavior." In Economic and

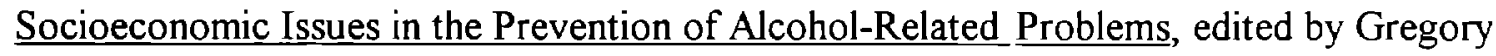
Bloss and Michael Hilton. National Institute on Alcohol Abuse and Alcoholism Research 
Monograph 25. NIH Publication No. 93-3513. Washington, D.C.: U.S. Government Printing Office 1993, 91-124.

Grossman, Michael; Chaloupka, Frank J.; and Sirtalan, Ismail. "An Empirical Analysis of Alcohol Addiction: Results from the Monitoring the Future Panels." National Bureau of Economic Research Working Paper No. 5200, revised March 1996.

Grossman, Michael; Coate, Douglas; and Arluck, Gregory M. "Price Sensitivity of Alcoholic Beverages in the United States." In Control Issues in Alcohol Abuse Prevention: Strategies for States and Communities, edited by Harold D. Holder. Greenwich, Connecticut: JAI Press, Inc., 1987, 169-198.

Heckman, James J. "Sample Selection Bias as a Specification Error." Econometrica, 46, No. 1 (January 1979), 153-161.

Hausman, Jerry A. "Specification Tests in Econometrics." Econometrica, 46, No. 6 (November 1978), $1251-1271$

Heckman, James J., and MaCurdy, Thomas E. "A Simultaneous Equations Linear Probability Model." Canadian Journal of Economics, 18, No. 1 (February 1985), 28-37.

Henningfield, Jack E.; Clayton, Richard; and Pollin, William. "Involvement of Tobacco in Alcoholism and Illicit Drug Use.” British Journal of Addiction, 85 (1990), 279-292. Henningfield, Jack E.; Cohen, Carolyn; and Slade, John E. "Is Nicotine More Addictive than Cocaine?" British Journal of Addiction, 86 (1991), 565-569.

Huber, Peter J. "The Behavior of Maximum Likelihood Estimates under Nonstandard Conditions." In Fifth Berkeley Symposium on Mathematical Statistics and Probability. Berkeley, California: University of California Press, 1967, 221-233. 
Johnston, Lloyd D.; O'Malley, Patrick M.; and Bachman, Jerald D. "Marijuana Decriminalization: The Impact on Youth, 1975-1980." Monitoring the Future Occasional Paper 13, Institute for Social Research, University of Michigan, 1981.

Johnston, Lloyd D.; O'Malley, Patrick M.; and Bachman, Jerald G. National Survey Results on Drug Use from the Monitoring the Future Study, 1975-1993. NIH Publication No. 943810. Washington, D.C.: U.S. Government Printing Office, 1994.

Johnston, Lloyd D.; O'Malley, Patrick M.; and Bachman, Jerald G. National Survey Results on Drug Use from the Monitoring the Future Study, 1975-1994. NIH Publication No. 954026. Washington, D.C.: U.S. Government Printing Office, 1995.

Kaplan, John. "Taking Drugs Seriously." The Public Interest, 92 (Summer 1988), 32-50.

Keeler, Theodore E.; Hu, Teh-wei; Barnett, Paul G.; and Manning, Willard G. "Taxation, Regulation, and Addiction: A Demand Function for Cigarettes Based on Time-Series Evidence." Journal of Health Economics, 12, No. 1 (April 1993), 1-18.

Kerr, Peter. "Anatomy of the Drug Issue: How, After Years, It Erupted." New York Times, November 17, 1986, A1, B6.

Kleiman, Mark A.R. Against Excess. New York: Basic Books, 1992.

Kloek, T. "OLS Estimation in a Model Where a Microvariable Is Explained by Aggregates and Contemporaneous Disturbances are Equicorrelated." Econometrica, 49, No. 1 (January 1981), 205-207.

Kozlowski, Lynn T.; Wilkinson, D. Adrian; Skinner, Wayne; Kent, Carl; Franklin, Tom; and Pope, Marilyn. "'“Comparing Tobacco Cigarette Dependence with Other Drug 
Dependencies." Journal of the American Medical Association, 26, No. 6 (February 10, 1989), 898-901.

Leland, John. “A Risky $R_{X}$ for Fun.” Newsweek, October 30, 1995, 74.

Lee, Li Way. "Would Harassing Drug Users Work?" Journal of Political Economy, 101, No. 5 (October 1993), 939-959.

Lin, Tsai-Fen, and Schmidt, Peter. "A Test of the Tobit Specification Against an Alternative Suggested by Cragg." Review of Economics and Statistics, 66, No. 1 (February 1984), 174-177.

Liu, Jin-Tan; Liu, Jin-Long; and Chow, Shin-Yi. "The Demand for Opium in Colonial Taiwan, 1914-1942." Working paper, National Taiwan University, May 1996.

Maddala, G.S. Limited-Dependent and Qualitative Variables in Economics. Cambridge, England: Cambridge University Press, 1983.

Manning, Willard G.; Duan, Naihu; and Rogers, William H. "Monte Carlo Evidence on the Choice Between Sample-Selection and Two-Part Models." Journal of Econometrics, 35, No. 1 (May 1987), 59-82.

Mobilia, Pamela. “An Economic Analysis of Addictive Behavior: The Case of Gambling." Ph.D. dissertation, City University of New York Graduate School, 1990.

Model, Karyn E. "The Effect of Marijuana Decriminalization on Hospital Emergency Room Drug Episodes: 1975-1978." Journal of the American Statistical Association, 88, No. 423 (September 1993), 737-747 
Moulton, Brent R. “An Illustration of a Pitfall in Estimating the Effects of Aggregate Variables on Micro Units." Review of Economics and Statistics, 72, No. 2 (May 1990), 334-338.

Musto, David F. The American Disease: Origins of Narcotics Control. New Haven, Connecticut: Yale University Press, 1973.

National Criminal Justice Association. A Guide to State Controlled Substances Acts. Washington, D.C.: National Criminal Justice Association, 1991.

National Institute on Drug Abuse, U.S. Department of Health and Human Services. National Household Survey on Drug Abuse: Main Findings 1990. DHHS Publication No. (ADM)91-1788, 1991.

Navarro, Mireya. "In South, Drug Abusers Turn to a Smuggled Sedative." New York Times, December 9, 1995, A15.

Nickell, Stephen. "Biases in Dynamic Models with Fixed Effects." Econometrica, 49, No. 6 (November 1981), 434-440.

Nisbet, Charles T., and Vakil, Firouz. "Some Estimates of Price and Expenditure Elasticities of Demand for Marijuana among U.C.L.A. Students." Review of Economics and Statistics, 54, No. 4 (November 1972), 473-475.

Orphanides, Athanasios, and Zervos, David. "Rational Addiction with Learning and Regret." Journal of Political Economy, 103, No. 4 (August 1995), 739-758

Purdy, Matthew. "New Inmates Reflect Surge in Use of Cheap but Potent Heroin." New York Times, December 3, 1995, 49, 52. 
Reuter, Peter, and Kleiman, Mark A.R. "Risks and Prices: An Economic Analysis of Drug Enforcement." In Crime and Justice, edited by M Michael H. Tonry and Norval Morris. Chicago: University of Chicago Press, 1986, 289-340.

Rhodes, William; Hyatt, Raymond; and Scheiman, Paul. "The Price of Cocaine, Heroin, and Marijuana, 1981-1993." Journal of Drug Issues, 24, No. 3 (Summer 1994), 383-402.

Rhodes, William, and Pittayathikhun, Tanutda. "Prices of Illicit Drugs: 1981-1996." Working Paper, Abt Associates, May 1996.

Saffer, Henry, and Chaloupka, Frank J. "The Demand for Illicit Drugs." National Bureau of Economic Research Working Paper No. 5238, revised March 1996.

Silverman, Lester P., and Spruill, Nancy L. "Urban Crime and the Price of Heroin." Journal of Urban Economics, 4, No. 1 (January 1977), 80-103.

Taubman, Paul. "Externalities and Decriminalization of Drugs." In Drug Policy in the United States, edited by Melvyn B. Krauss and Edward P. Lazear. Stanford, California: Hoover Institution Press, 90-111.

Thies, C. F. , and Register, C. A. "Decriminalization of Marijuana and the Demand for Alcohol, Marijuana, and Cocaine." The Social Science Journal, 30, No. 4 (1993), 385-399.

Tregarthen, Timothy. "The Drug War: Battling Supply and Demand." The Margin (January/February 1990), 17-22.

Van Ours, Jan C. "The Price Elasticity of Hard Drugs: The Case of Opium in the Dutch East Indies, 1923-1938." Journal of Political Economy, 103, No. 2 (April 1995), 261-279. 


\section{FOOTNOTES}

Research for this paper was supported by grant 5 R01 DA07533 from the National Institute on Drug Abuse to the National Bureau of Economic Research. We are extremely grateful to Patrick J. O'Malley, Senior Research Scientist at the University of Michigan's Institute for Social Research, for providing us with selected data from the Monitoring the Future panels and for variance-covariance matrixes containing illegal drug use and illegal drug prices. We also are extremely grateful to Jerome J. Hiniker, Senior Research Scientist at ISR, for creating the computer programs that produced these tapes. We owe a special debt to Carolyn G. Hoffman, Chief of the Statistical Analysis Unit of the U.S. Department of Justice Drug Enforcement Administration, for providing us with illegal drug prices from the System to Retrieve Information from Drug Evidence (STRIDE). Part of the research for this paper was completed while Grossman was a visiting scholar at the Institute for Research on Economics and Society (IRES) at the Catholic University of the Louvain in Belgium, and he wishes to acknowledge the financial support provided by that institution. We are indebted to Gary S. Becker, Warren K. Bickel, Jonathan P. Caulkins, Richard Clayton, Jack E. Henningfield, Matthew E. Kahn, Mark A.R. Kleiman, John R. Lott, Jr., Willard G. Manning, Jacob Mincer, Derek Neal, Robert Ohsfeldt, Solomon W. Polachek, William Rhodes, Sherwin Rosen, Henry Saffer, Robert H. Topel, and Joseph Tracey for helpful comments and suggestions. Preliminary versions of this paper were presented at the 1996 Western Economic Association International Conference, the 1996 International Health Economics Association Conference, the 1996 Pacific Rim Allied Economic Organization Conference and at seminars at the University of Chicago, Columbia University, and the State University of New York at Binghamton. We are indebted to the participants in those 
conferences and seminars for comments and suggestions. Finally, we wish to thank Sara Markowitz, Ismail Sirtalan, Timothy Perry, Patricia Kocagil, and Abeni Crooms for research assistance. This paper has not undergone the review accorded official NBER publications; in particular it has not been submitted for approval by the Board of Directors.

${ }^{1}$ See Reuter and Kleiman (1986), Kaplan (1988), Tregarthen (1989), and Kleiman (1992) for rough estimates of these reductions.

${ }^{2}$ See Grossman (1993) for a summary of this research.

${ }^{3}$ This may be traced to attempts to fit the rational addiction model to relatively short time series of aggregate data.

${ }^{4}$ Dealers may be less sensitive to price than non-dealers because an increase in price raises the real income of the former group, while it lowers the real income of the latter group. Hence, if heroin is a superior good, the substitution and income effects of a price reduction go in opposite directions for dealers.

${ }^{5}$ Equation (1) assumes that the rate of depreciation on the addictive stock is equal to one, so that the stock is replaced by lagged consumption $\left(\mathrm{C}_{\mathrm{t}-1}\right)$ in the current period utility function. Grossman, Chaloupka, and Sirtalan (1996) report that empirical results for a model with a rate of depreciation smaller than one are very similar to those for a model with a rate of depreciation equal to one in the case of alcohol. Equation (1) also assumes no uncertainty about becoming addicted. For an analysis that alters this assumption without changing the basic predictions of the rational addiction model, see Orphanides and Zervos (1995)

${ }^{6}$ There is no odd-numbered calendar year panel from the 1976 baseline survey. 
${ }^{7}$ For the A panels, the first value of past consumption only coincides with the first annual lag of consumption. The same comment applies to lagged values of socioeconomic characteristics, the price of cocaine, and related variables which are discussed below. From now on, we refer to the past value of a given variable as its second lag even though the first past value is the first lag for the A panels. In preliminary estimation, we found that results obtained for the B panels only were very similar to those reported in Section IV.

${ }^{8}$ Trends in the National Households Surveys on Drug Abuse between 1976 and 1990 are based on surveys taken in 1976, 1977, 1979, 1982, 1985, 1988, and 1990.

${ }^{9}$ Weight and purity are measured in DEA laboratories. STRIDE is described in detail by Frank (1987), DiNardo (1993), and Caulkins (1994).

${ }^{10}$ Missing data for some cities in certain years preclude a specification with city-time or state-time interactions

${ }^{11}$ We also experimented with deflation by a city-specific cost of living index multiplied by the annual CPI for the U.S. as a whole. The city index is the one reported by the American Chamber of Commerce Researchers Association (ACCRA various years) and described in detail by Grossman, Chaloupka, and Sirtalan (1996). Preliminary results with this price variable were similar to those contained in Section IV. We do not emphasize estimates with it because in many cases an ACCRA city must be matched to a different DEA city.

${ }^{12}$ Except in two cases, the price from one state was never assigned to residents of another state. The Washington, D.C. MSA includes portions of Virginia and Maryland. Those living within this MSA were given the D.C. price even if they lived in Virginia or Maryland. The Kansas City, Kansas-Kansas City, Missouri MSA includes residents of two states. The DEA city pertains 
to Missouri. All residents of the MSA were given the same price since neither state is the dominant one in the population of the MSA. Although St. Louis, Missouri also is a DEA city, residents of Kansas City, Missouri were not assigned a state-weighted average price because the distance between the two cities is very large.

${ }^{13}$ Recall that the first value of lagged price is the first annual lag for the A panels. In addition, for the B panel from the 1976 baseline, the first value of lagged price pertains to 1977 since there are no cocaine prices prior to that year.

${ }^{14}$ In an accounting sense, the decline in price between 1978 and 1987 can be traced to a large increase in purity from 32 percent in the former year to 73 percent in the latter year and to a modest 12 percent decline in the money price of one gram of cocaine not adjusted for purity at the same time as the Consumer Price Index rose by 75 percent.

${ }^{15}$ Much of the above discussion is based on a personal conversation with Jonathan $P$. Caulkins.

${ }^{16}$ If the supply curve of cocaine slopes upward and the expected penalties for use and distribution are positively related, the positive correlation between the money price and the full price is reduced but not eliminated. Lee (1993) reaches somewhat different conclusions than those in the text, but he assumes an upward-sloping supply curve and a Cobb-Douglas utility function. Moreover, he holds the expected penalty per contact with users imposed on dealers constant. In the context of our analysis, if the expected penalty imposed on users ( $f$ ) is proportional to the money price of cocaine and the supply function is infinitely elastic, the price elasticity of demand is not biased by the omission of $f$. To see this, define full price $(\pi)$ as the sum 
of money price ( $p$ ) and $f$, and let $f=k p$, where $k$ is a constant. If the demand function is linear, it can be written as

$$
c=\alpha-\beta \pi=\alpha-\beta(1+k) p
$$

The elasticity of $\mathrm{c}$ with respect to $\pi$ is

$$
\varepsilon=\beta \pi c^{-1}=\beta p(1+k) c^{-1}
$$

Along the same lines, one can show that the elasticity of $c$ with respect to $p$ is smaller than the elasticity of $\mathrm{c}$ with respect to $\pi$ if $\mathrm{f}=\mathrm{a}+\mathrm{kp}, \mathrm{a}>0$ or if $\mathrm{f}=\mathrm{kp}^{\gamma}, \gamma<1$. For $\gamma>1$ the money price elasticity exceeds the full price elasticity.

${ }^{17}$ DiNardo and Lemieux (1992) report that an increase in the legal drinking age increases the percentage of high school seniors who used marijuana in the past month. They also find that the percentage of high school seniors who used alcohol in the past month is lower in states that decriminalized marijuana. Decriminalization, however, has no impact on the use of marijuana These findings are based on the time series of state cross sections used by DiNardo (1993) and described in Section I. Using individual observations from the 1989 Monitoring the Future baseline surveys, Chaloupka and Laixuthai (1994) indicate that monthly or annual alcohol consumption is lower in states that decriminalized marijuana and is positively related to the money price of marijuana. They do not study marijuana consumption and their marijuana price is taken from a DEA source other than STRIDE that contains data for 19 cities in 16 states. Taken together, the two studies suggest that marijuana and alcohol are substitutes.

${ }^{18}$ The construction of this variable accounts for the grandfather clauses many states adopted when raising their legal ages for all alcoholic beverages to 21 years to comply with the Federal Uniform Drinking Age Act of 1984. Similar variables were constructed for high alcohol 
beer and for distilled spirits. The three series are extremely highly correlated, and the choice of the drinking age variable has little impact on the resulting estimates. For more details on the construction of the drinking age measure, see Chaloupka, Saffer, and Grossman (1993).

${ }^{19}$ Money earnings are deflated by a city-specific cost-of living-index multiplied by the annual CPI for the U.S. as a whole. The city index is the one reported by the ACCRA (see note 11 and Grossman, Chaloupka, and Sirtalan 1996).

${ }^{20}$ Full-time work status and full-time college student status are not mutually exclusive categories in theory or in the followup questionnaires.

${ }^{21}$ The regressions presented in Section IV do not include age-time interactions because these interactions are not significant as a set. But this is in the context of a specification that controls for past and future consumption.

${ }^{22}$ For detailed discussions of the Cragg and Heckman procedures, see Lin and Schmidt (1984) and Manning, Duan, and Rogers (1987). The latter authors refer to Cragg's model as the two-part model.

${ }^{23}$ The sample of positive current users includes persons whose past or future values of use can be zero. In fact, the weighted means of past and future participation are 64 percent and 69 percent, respectively.

${ }^{24}$ In some specifications the current legal drinking age and marijuana decriminalization measures are omitted from the demand functions. In these specifications the past values of the drinking age variables and the past and future values of the decriminalization indicator are not employed as instruments. 
${ }^{25}$ Full-time workers at baseline are students who work more than 20 hours per week during the school year.

${ }^{26}$ The only income question in the followup surveys pertains to own earnings

${ }^{27}$ Kloek (1981) and Moulton (1990) argue that t-ratios of coefficients of aggregate variables in micro regressions are biased downward if the disturbances in the regression are correlated among persons who live in the same area. This assumes, however, that the aggregate variable is measured without error. Another mitigating factor is that Kloek (1981) shows that the bias in the t-ratios increases as the number of people in each group (in our case, the county) rises. We have a small number of observations from a given county. A related issue pertains to the effects of the panel nature of the sample on standard errors of regression coefficients. In particular, the disturbance terms for a given person are likely to be correlated over time. Grossman, Chaloupka, and Sirtalan (1996) find that Huber (1967) standard errors, which take account of these correlations, are no larger than uncorrected standard errors in their study of rational addiction demand functions for alcohol in the Monitoring the Future panels.

${ }^{28}$ These estimates would have to be corrected for sample selection using Heckman's (1979) methodology. Identification by means other than the nonlinear relationship between the inverse of the Mills ratio and the regressors is highly problematic.

${ }^{29}$ Strictly speaking, equation (2) in the text pertains to a continuous outcome. Therefore, the estimates in Table 2 and their implied discount factors should be viewed as first-order approximations.

${ }^{30}$ The participation elasticities in the first model in Table 5 are smaller than the corresponding elasticities in Table 4, even though the price and consumption coefficients in the 
two models appear to be very similar. Indeed the price coefficients appear to be identical. They are very small numbers (.0001 in absolute value to four decimal places). But the computation of the elasticities uses more than four decimal places.

${ }^{31}$ If individuals did not move among counties, the fixed-effect specification would fully control for unmeasured county-specific factors since county dichotomous variables would be time-invariant. Along the same lines, if persons move among counties but not among states, unmeasured state-specific factors are eliminated. More generally, the fixed-effects model reduces biases due to unmeasured area-specific forces.

${ }^{32}$ Although the models in Table 6 contain the same time-varying regressors as the models in Tables 2 and 3, it is not surprising that the Hausman test decisively rejects OLS in Table 6 but not in Tables 2 and 3. Nickell (1981) shows that fixed-effects OLS estimation produces a negative bias and inconsistency in the coefficient of the lagged dependent variable in the absence of serial correlation. Using his techniques, one can demonstrate that the coefficients of past and future consumption are understated in the OLS fixed-effects model. Indeed, we obtain negative past and future consumption coefficients when this procedure is used. 
Figure 1

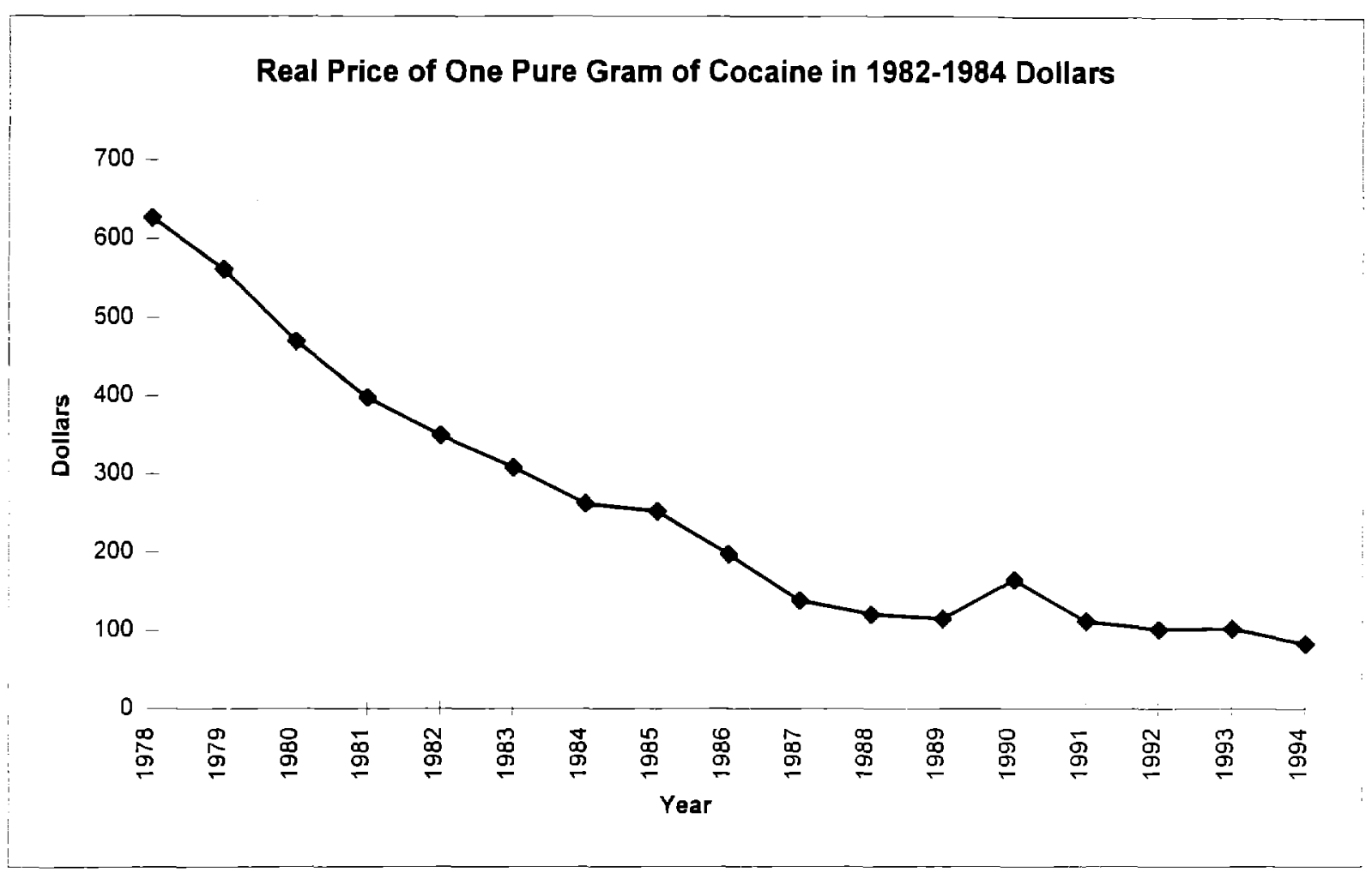

Figure 2

Cocaine Participation and Frequency Given Positive Participation,

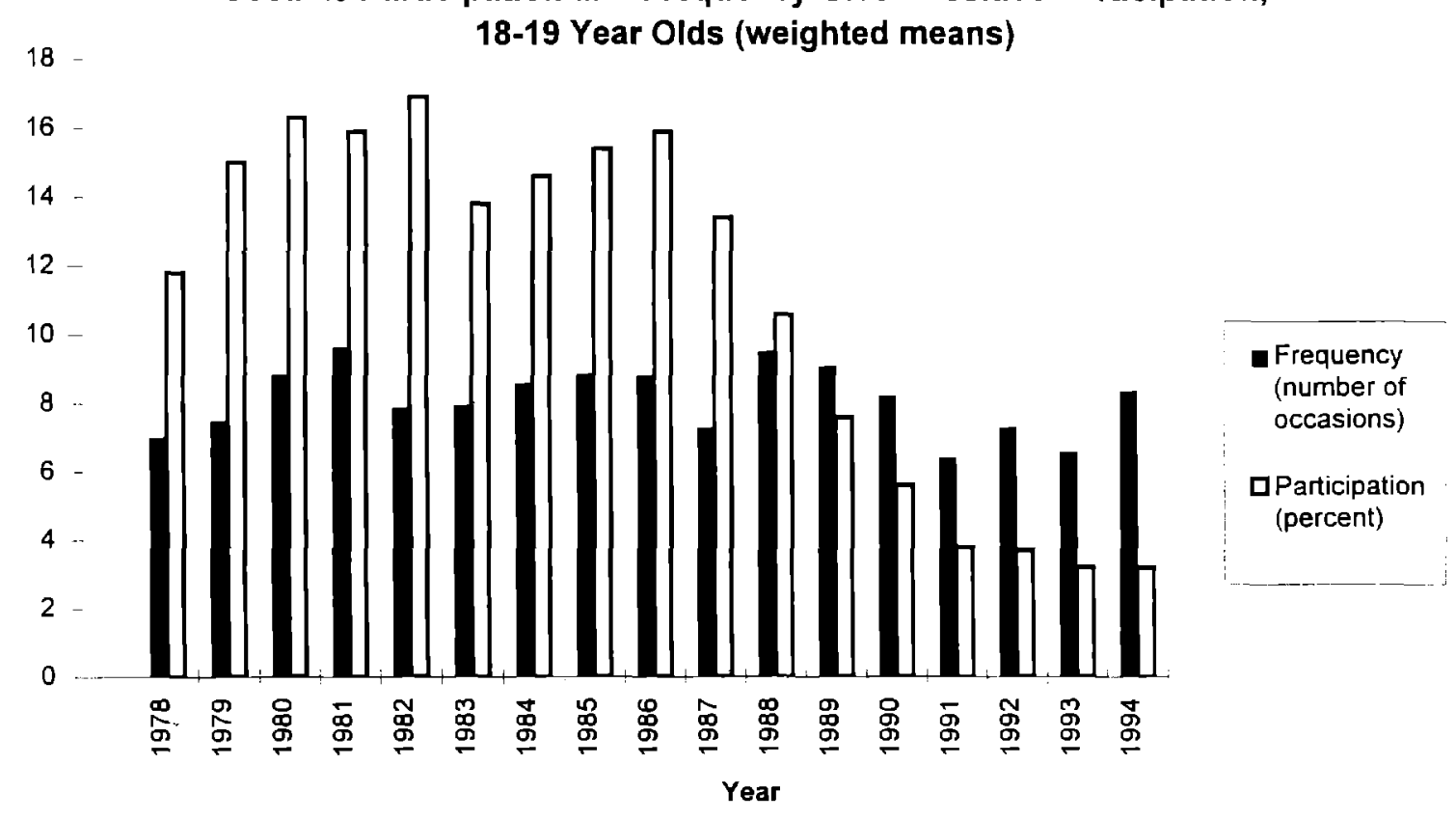


Table 1

Definitions, Means, and Standard Deviations of Variables ${ }^{a}$

Cocaine participation

$(0.159,0.320)$

Cocaine frequency given positive participation $(9.195,8.963)$

Price

(286.557, 117.204)

Legal drinking age*age $\leq 21$

(12.093, 8.409)

Lower border drinking age

indicator*age $\leq 21$

$(0.099 .0 .261)$

Marijuana decriminalization indicator $(0.330 .0 .411)$

\section{Age 18}

$(0.169,0.328)$

Age 19

$(0.180 .0 .336)$

Age 20

(0.136. 0.300)

Age 21

$(0.130,0.295)$

Age 22

$(0.100,0.262)$

Age 23

$(0.096,0.258)$

Age 24

$(0.065,0.216)$

Age 25

$(0.063,0.213)$

Age 26

$(0.031,0.151)$
Dichotomous variable that equals 1 if respondent used cocaine at least once in the past year

Number of occasions in past year on which respondent used cocaine

Price of one pure gram of cocaine in 1982-84 dollars ${ }^{\circ}$

Minimum legal age in years for purchase and consumption of beer, alcoholic content 3.2 percent or less (legal drinking age); multiplied by a dichotomous variable that equals 1 if respondent is 21 years of age or younger $(\text { age } \leq 21)^{b}$

Dichotomous variable that equals 1 if respondent resides in a county within 25 miles of a state with a lower legal drinking age (lower border age indicator); multiplied by a dichotomous variable that equals 1 if respondent is 21 years of age or younger

Dichotomous variable that equals 1 if respondent resides in a state in which incarceration and heavy fines are not penalties for most marijuana possession offenses

Dichotomous variables that identify respondents aged 18, 19, 20,21, 22, $23,24,25$, and 26 respectively; omitted category pertains to respondents aged 27 
Male

$(0.438,0.434)$

\section{Black}

(0.091, 0.252)

Other race/ethnicity

$(0.068,0.221)$

Real earnings

$(7.447 .845 .5 .880 .433)$

Years of completed schooling

(13.357. 1.355)

Full-time college student

(0.334. 0.410)

Half-time college student

$(0.037,0.164)$

Less than half-time college student

$(0.054,0.196)$

Working full-time

$(0.530,0.428)$

Working part-time

(0.215. 0.352)

Unemployed

$(0.031 .0 .149)$

Infrequent religious participation

$(0.410,0.428)$

Frequent religious participation

$(0.487,0.435)$

Married

(0.255. 0.381)

Engaged

(0.084, 0.242)

Separated or divorced

(0.024. 0.134)
Dichotomous indicator

Dichotomous variables that identify

Afro-Americans or blacks (Black) and

American Indians, Puerto Ricans or

other Latin Americans, Mexican

Americans or Chicanos, or Orientals

or Asian Americans (Other

race/ethnicity); omitted category

pertains to Caucasians or whites

Real earnings in the past calendar year in 1982-84 dollars; money earnings divided by a year- and city-specific cost of living index

Years of formal schooling completed

Dichotomous indicators; omitted category pertains to persons not attending school in March of the survey year

Dichotomous indicators that pertain to first full week of March of the survey year: omitted category identifies respondents not in the labor force

Dichotomous variables that identify respondents who rarely attend religious services (infrequent religious participation) and who attend religious services at least once or twice a month (frequent religious participation), respectively; omitted category pertains to respondents who never attend religious services

Dichotomous indicators; omitted category pertains to single respondents 
Number of children

$(0.229,0.499)$

1978

$(0.032,0.155)$

1979

$(0.036,0.164)$

1980

$(0.068,0.220)$

1981

$(0.072,0.226)$

1982

$(0.103,0.266)$

1983

$(0.107,0.270)$

1984

$(0.141,0.304)$

1985

$(0.136,0.300)$

1986

$(0.164,0.324)$
Respondent's number of children

Dichotomous variables for followups conducted in years specified; omitted year is 1987

${ }^{2}$ Means and standard deviations in parentheses. First figure is mean, second figure is standard deviation. Means and standard deviations are weighted by the inverse of the probability of selection; equivalent to multiplying values of a given variable from the illegal drug stratum by one-third. Sample size is 38.885 except for cocaine frequency given positive participation where the sample size is 8.926 .

"See text for more details. 
Table 2

Structural Demand Functions

Dependent Variable=Participation

\begin{tabular}{|c|c|c|c|c|}
\hline & \multicolumn{2}{|c|}{ Two-Stage Least Squares } & \multicolumn{2}{|c|}{ Ordinary Least Squares } \\
\hline & (1) & (2) & (3) & (4) \\
\hline Price & $\begin{array}{l}-0.0001 \\
(-5.22)\end{array}$ & $\begin{array}{l}-0.0001 \\
(-4.63)\end{array}$ & $\begin{array}{l}-0.0002 \\
(-6.70)\end{array}$ & $\begin{array}{l}-0.0002 \\
(-5.86)\end{array}$ \\
\hline Past participation & $\begin{array}{c}0.381 \\
(9.92)\end{array}$ & $\begin{array}{r}0.381 \\
(10.09)\end{array}$ & $\begin{array}{r}0.378 \\
(86.10)\end{array}$ & $\begin{array}{r}0.377 \\
(85.93)\end{array}$ \\
\hline Future participation & $\begin{array}{r}0.452 \\
(14.17) \\
\end{array}$ & $\begin{array}{r}0.449 \\
(14.16)\end{array}$ & $\begin{array}{r}0.408 \\
(95.46)\end{array}$ & $\begin{array}{r}0.408 \\
(95.38)\end{array}$ \\
\hline Marijuana decriminalization & & $\begin{array}{r}0.008 \\
(2.13)\end{array}$ & & $\begin{array}{c}0.008 \\
(2.29)\end{array}$ \\
\hline Legal drinking age*age $\leq 21$ & & $\begin{array}{r}0.004 \\
(2.36)\end{array}$ & & $\begin{array}{r}0.004 \\
(2.55)\end{array}$ \\
\hline Lower border drinking age indicator*age $\leq 21$ & & $\begin{array}{c}0.008 \\
(1.48)\end{array}$ & & $\begin{array}{r}0.010 \\
(1.89)\end{array}$ \\
\hline Age 18 & $\begin{array}{r}-0.044 \\
(-3.58) \\
\end{array}$ & $\begin{array}{l}-0.130 \\
(-3.40)\end{array}$ & $\begin{array}{l}-0.047 \\
(-4.01)\end{array}$ & $\begin{array}{c}-0.139 \\
(-3.74)\end{array}$ \\
\hline Age 19 & $\begin{array}{r}-0.015 \\
(-1.24) \\
\end{array}$ & $\begin{array}{l}-0.100 \\
(-2.63)\end{array}$ & $\begin{array}{c}-0.017 \\
(-1.50)\end{array}$ & $\begin{array}{l}-0.108 \\
(-2.93)\end{array}$ \\
\hline $4 \mathrm{ge} 20$ & $\begin{array}{c}-0.008 \\
(-0.69) \\
\end{array}$ & $\begin{array}{l}-0.093 \\
(-2 .+6)\end{array}$ & $\begin{array}{c}-0.010 \\
(-0.87)\end{array}$ & $\begin{array}{c}-0.101 \\
(-2.73)\end{array}$ \\
\hline Age 2! & $\begin{array}{r}0.000 \\
(-0.03) \\
\end{array}$ & $\begin{array}{r}-0.086 \\
(-2.28) \\
\end{array}$ & $\begin{array}{c}-0.002 \\
(-0.15) \\
\end{array}$ & $\begin{array}{r}-0.093 \\
(-2.52) \\
\end{array}$ \\
\hline Age 22 & $\begin{array}{r}0.010 \\
(0.89) \\
\end{array}$ & $\begin{array}{r}0.009 \\
(0.85) \\
\end{array}$ & $\begin{array}{c}0.009 \\
(0.80)\end{array}$ & $\begin{array}{r}0.008 \\
(0.76)\end{array}$ \\
\hline Age 23 & $\begin{array}{r}0.006 \\
(0.56) \\
\end{array}$ & $\begin{array}{c}0.006 \\
(0.52) \\
\end{array}$ & $\begin{array}{c}0.006 \\
(0.55) \\
\end{array}$ & $\begin{array}{r}0.005 \\
(0.51) \\
\end{array}$ \\
\hline Age 24 & $\begin{array}{r}0.002 \\
(0.22) \\
\end{array}$ & $\begin{array}{r}0.002 \\
(0.20) \\
\end{array}$ & $\begin{array}{r}0.002 \\
(0.16) \\
\end{array}$ & $\begin{array}{r}0.002 \\
(0.15) \\
\end{array}$ \\
\hline Age 25 & $\begin{array}{r}0.002 \\
(0.22) \\
\end{array}$ & $\begin{array}{r}0.002 \\
(0.21) \\
\end{array}$ & $\begin{array}{r}0.002 \\
(0.20)\end{array}$ & $\begin{array}{r}0.002 \\
(0.19)\end{array}$ \\
\hline dge 26 & $\begin{array}{r}-0.023 \\
(-1.84) \\
\end{array}$ & $\begin{array}{r}0.001 \\
(0.31) \\
\end{array}$ & $\begin{array}{r}-0.023 \\
(-1.85)\end{array}$ & $\begin{array}{l}-0.023 \\
(-1.84)\end{array}$ \\
\hline Male & $\begin{array}{r}0.001 \\
(0.24) \\
\end{array}$ & $\begin{array}{r}-0.023 \\
(-1.83) \\
\end{array}$ & $\begin{array}{r}0.004 \\
(1.10) \\
\end{array}$ & $\begin{array}{r}0.004 \\
(1.15) \\
\end{array}$ \\
\hline Black & $\begin{array}{r}-0.023 \\
(-3.74)\end{array}$ & $\begin{array}{r}-0.022 \\
(-3.58)\end{array}$ & $\begin{array}{r}-0.027 \\
(-4.68)\end{array}$ & $\begin{array}{r}-0.026 \\
(-4.45)\end{array}$ \\
\hline Other race/ethnicity & $\begin{array}{l}-0.008 \\
(-1.33)\end{array}$ & $\begin{array}{r}-0.009 \\
(-1.52)\end{array}$ & $\begin{array}{l}-0.009 \\
(-1.47)\end{array}$ & $\begin{array}{l}-0.010 \\
(-1.67)\end{array}$ \\
\hline Real earnings & $\begin{array}{l}0.0000004 \\
(1.42)\end{array}$ & $\begin{array}{l}0.0000004 \\
(1.47)\end{array}$ & $\begin{array}{l}0.0000005 \\
(1.57)\end{array}$ & $\begin{array}{l}0.0000005 \\
(1.63)\end{array}$ \\
\hline Years of completed schooling & $\begin{array}{r}0.000 \\
(-0.07) \\
\end{array}$ & $\begin{array}{r}0.000 \\
(-0.11) \\
\end{array}$ & $\begin{array}{l}-0.001 \\
(-0.41)\end{array}$ & $\begin{array}{r}-0.001 \\
(-0.43)\end{array}$ \\
\hline Full-time college student & $\begin{array}{r}-0.007 \\
(-1.44)\end{array}$ & $\begin{array}{l}-0.007 \\
(-1.46)\end{array}$ & $\begin{array}{l}-0.007 \\
(-1.54)\end{array}$ & $\begin{array}{c}-0.008 \\
(-1.57)\end{array}$ \\
\hline Half-time college student & $\begin{array}{r}0.002 \\
(0.23) \\
\end{array}$ & $\begin{array}{r}0.002 \\
(0.20) \\
\end{array}$ & $\begin{array}{r}0.003 \\
(0.31) \\
\end{array}$ & $\begin{array}{r}0.002 \\
(0.27) \\
\end{array}$ \\
\hline Less than half-time college student & $\begin{array}{c}-0.003 \\
(-0.46)\end{array}$ & $\begin{array}{c}-0.004 \\
(-0.51)\end{array}$ & $\begin{array}{c}-0.003 \\
(-0.41)\end{array}$ & $\begin{array}{r}-0.003 \\
(-0.46)\end{array}$ \\
\hline Working füll-time & $\begin{array}{l}-0.002 \\
(-0.36)\end{array}$ & $\begin{array}{c}-(0.002 \\
(-0.37)\end{array}$ & $\begin{array}{l}-0.002 \\
(-0.47)\end{array}$ & $\begin{array}{l}-0.002 \\
(-0.48)\end{array}$ \\
\hline Working part-time & $\begin{array}{r}-0.001 \\
(-0.21)\end{array}$ & $\begin{array}{r}-0.001 \\
(-0.25)\end{array}$ & $\begin{array}{c}-0.001 \\
(-0.27)\end{array}$ & $\begin{array}{r}-0.001 \\
(-0.30)\end{array}$ \\
\hline
\end{tabular}




\begin{tabular}{||l|c|c|c|c||}
\hline Unemployed & 0.013 & 0.013 & 0.014 & 0.013 \\
& $(1.38)$ & $(1.35)$ & $(1.45)$ & $(1.41)$ \\
\hline Infrequent religious participation & -0.013 & -0.012 & -0.014 & -0.014 \\
& $(-2.44)$ & $(-2.38)$ & $(-2.73)$ & $(-2.66)$ \\
\hline Frequent religious participation & -0.053 & -0.052 & -0.062 & -0.061 \\
& $(-7.23)$ & $(-7.24)$ & $(-11.79)$ & $(-11.63)$ \\
\hline Marnied & -0.050 & -0.050 & -0.056 & -0.056 \\
& $(-9.16)$ & $(-9.18)$ & $(-12.25)$ & $(-12.17)$ \\
\hline Engaged & -0.011 & -0.011 & -0.014 & -0.013 \\
& $(-1.83)$ & $(-1.84)$ & $(-2.39)$ & $(-2.36)$ \\
\hline Separated or divorced & -0.002 & -0.002 & -0.003 & -0.002 \\
& $(-0.21)$ & $(-0.18)$ & $(-0.26)$ & $(-0.23)$ \\
\hline Number of children & -0.008 & -0.008 & -0.008 & -0.008 \\
& $(-2.25)$ & $(-2.23)$ & $(-2.39)$ & $(-2.37)$ \\
\hline 1978 & 0.067 & 0.067 & 0.080 & 0.081 \\
& $(4.01)$ & $(3.93)$ & $(5.24)$ & $(5.13)$ \\
\hline 1979 & 0.089 & 0.090 & 0.103 & 0.103 \\
& $(5.72)$ & $(5.60)$ & $(7.24)$ & $(7.08)$ \\
\hline 1980 & 0.070 & 0.070 & 0.081 & 0.081 \\
& $(5.70)$ & $(5.61)$ & $(7.45)$ & $(7.29)$ \\
\hline 1981 & 0.050 & 0.050 & 0.060 & 0.060 \\
& $(4.53)$ & $(4.48)$ & $(6.28)$ & $(6.16)$ \\
\hline 1982 & 0.046 & 0.045 & 0.054 & 0.054 \\
& $(4.82)$ & $(4.72)$ & $(6.50)$ & $(6.33)$ \\
\hline 1983 & 0.030 & 0.030 & 0.038 & 0.038 \\
& $(3.38)$ & $(3.34)$ & $(5.02)$ & $(4.92)$ \\
\hline 1984 & 0.026 & 0.026 & 0.033 & 0.032 \\
& $(3.50)$ & $(3.42)$ & $(4.90)$ & $(4.76)$ \\
\hline 1985 & 0.054 & 0.054 & 0.059 & 0.058 \\
& $(7.77)$ & $(7.68)$ & $(8.93)$ & $(8.80)$ \\
\hline 1986 & 0.043 & 0.043 & 0.045 & 0.045 \\
& $(7.20)$ & $(7.17)$ & $(7.84)$ & $(7.79)$ \\
\hline R-squared & 0.179 & 0.181 & 0.486 & $(0.486$ \\
\hline Hausman chi-squared & 4.165 & 3.815 & & \\
\hline $\mathrm{N}$ & 38.885 & 38.885 & 38.885 & 38.885 \\
\hline & & & & \\
\hline
\end{tabular}

Note: Asymptoric t-statistics in parentheses, and intercepts not shown. 
Table 3

Structural Demand Functions

Dependent Variable=Frequency

\begin{tabular}{|c|c|c|c|c|}
\hline & \multicolumn{2}{|c|}{ Two-Stage Least Squares } & \multicolumn{2}{|c|}{ Ordinary Least Squares } \\
\hline & (1) & (2) & (3) & (4) \\
\hline Price & $\begin{array}{c}-0.008 \\
(-3.29)\end{array}$ & $\begin{array}{c}-0.008 \\
(-3.13)\end{array}$ & $\begin{array}{c}-0.006 \\
(-2.99)\end{array}$ & $\begin{array}{l}-0.005 \\
(-2.51)\end{array}$ \\
\hline Past frequency & $\begin{array}{r}0.247 \\
(2.74)\end{array}$ & $\begin{array}{c}0.218 \\
(2.51)\end{array}$ & $\begin{array}{r}0.314 \\
(29.61)\end{array}$ & $\begin{array}{r}0.313 \\
(29.56)\end{array}$ \\
\hline Future frequency & $\begin{array}{r}0.223 \\
(3.92) \\
\end{array}$ & $\begin{array}{r}0.225 \\
(3.95)\end{array}$ & $\begin{array}{r}0.302 \\
(31.96)\end{array}$ & $\begin{array}{r}0.302 \\
(31.94)\end{array}$ \\
\hline Marijuana decriminalization & & $\begin{array}{r}0.250 \\
(0.89)\end{array}$ & & $\begin{array}{r}0.203 \\
(0.75)\end{array}$ \\
\hline Legal drinking age*age $\leq 21$ & & $\begin{array}{r}0.149 \\
(1.03)\end{array}$ & & $\begin{array}{c}0.144 \\
(1.00)\end{array}$ \\
\hline Lower border drinking age indicator*age $\leq 21$ & & $\begin{array}{r}0.455 \\
(1.03)\end{array}$ & & $\begin{array}{r}0.283 \\
(0.66)\end{array}$ \\
\hline Age 18 & $\begin{array}{l}-1.840 \\
(-1.47)\end{array}$ & $\begin{array}{r}-5.187 \\
(-1.59)\end{array}$ & $\begin{array}{l}-1.070 \\
(-1.07)\end{array}$ & $\begin{array}{l}-4.046 \\
(-1.31)\end{array}$ \\
\hline Age 19 & $\begin{array}{c}-0.911 \\
(-0.71)\end{array}$ & $\begin{array}{r}-4.282 \\
(-1.31)\end{array}$ & $\begin{array}{c}-0.071 \\
(-0.08)\end{array}$ & $\begin{array}{l}-3.035 \\
(-0.99)\end{array}$ \\
\hline Age 20 & $\begin{array}{c}-0.856 \\
(-0.72) \\
\end{array}$ & $\begin{array}{r}-4.166 \\
(-1.30)\end{array}$ & $\begin{array}{r}-0.182 \\
(-0.20)\end{array}$ & $\begin{array}{r}-3.132 \\
(-1.03)\end{array}$ \\
\hline Age 2I & $\begin{array}{c}-1.015 \\
(-0.90)\end{array}$ & $\begin{array}{r}-4.303 \\
(-1.35)\end{array}$ & $\begin{array}{c}-0.428 \\
(-0.47)\end{array}$ & $\begin{array}{l}-3.376 \\
(-1.11)\end{array}$ \\
\hline Age 22 & $\begin{array}{r}-0.563 \\
(-0.53)\end{array}$ & $\begin{array}{c}-0.754 \\
(-0.71)\end{array}$ & $\begin{array}{r}-0.039 \\
(-0.04)\end{array}$ & $\begin{array}{r}-0.065 \\
(-0.07)\end{array}$ \\
\hline Age 23 & $\begin{array}{c}-0.695 \\
(-0.69)\end{array}$ & $\begin{array}{c}-0.848 \\
(-0.85)\end{array}$ & $\begin{array}{c}-0.331 \\
(-0.37)\end{array}$ & $\begin{array}{l}-0.353 \\
(-0.39)\end{array}$ \\
\hline $\operatorname{Age} 24$ & $\begin{array}{r}-0.171 \\
(-0.17)\end{array}$ & $\begin{array}{c}-0.275 \\
(-0.28)\end{array}$ & $\begin{array}{r}0.200 \\
(0.22)\end{array}$ & $\begin{array}{c}0.188 \\
(0.20)\end{array}$ \\
\hline Age 25 & $\begin{array}{c}-0.102 \\
(-0.10)\end{array}$ & $\begin{array}{c}-0.216 \\
(-0.22)\end{array}$ & $\begin{array}{r}0.229 \\
(0.25)\end{array}$ & $\begin{array}{r}0.226 \\
(0.24)\end{array}$ \\
\hline Age 26 & $\begin{array}{l}-2.250 \\
(-2.03)\end{array}$ & $\begin{array}{l}-2.316 \\
(-2.08)\end{array}$ & $\begin{array}{c}-1.971 \\
(-1.82)\end{array}$ & $\begin{array}{l}-1.973 \\
(-1.82)\end{array}$ \\
\hline Male & $\begin{array}{c}-0.348 \\
(-1.31)\end{array}$ & $\begin{array}{c}-0.336 \\
(-1.26)\end{array}$ & $\begin{array}{c}-0.456 \\
(-1.79)\end{array}$ & $\begin{array}{l}-0.452 \\
(-1.77)\end{array}$ \\
\hline Black & $\begin{array}{l}-1.218 \\
(-1.85)\end{array}$ & $\begin{array}{l}-1.280 \\
(-1.95)\end{array}$ & $\begin{array}{l}-1.019 \\
(-1.67)\end{array}$ & $\begin{array}{l}-1.005 \\
(-1.64)\end{array}$ \\
\hline Other race/ethniciry & $\begin{array}{r}0.569 \\
(1.18)\end{array}$ & $\begin{array}{r}0.533 \\
(1.10)\end{array}$ & $\begin{array}{r}0.588 \\
(1.23)\end{array}$ & $\begin{array}{c}0.557 \\
(1.16)\end{array}$ \\
\hline Real eamings & $\begin{array}{l}0.0001 \\
(3.55)\end{array}$ & $\begin{array}{l}0.0001 \\
(3.59)\end{array}$ & $\begin{array}{l}0.0001 \\
(3.35)\end{array}$ & $\begin{array}{l}0.0001 \\
(3.35)\end{array}$ \\
\hline Years of completed schooling & $\begin{array}{r}-0.356 \\
(-3.04)\end{array}$ & $\begin{array}{r}-0.366 \\
(-3.13)\end{array}$ & $\begin{array}{c}-0.258 \\
(-2.52)\end{array}$ & $\begin{array}{l}-0.257 \\
(-2.51)\end{array}$ \\
\hline Full-time college student & $\begin{array}{c}-1.301 \\
(-3.30)\end{array}$ & $\begin{array}{c}-1.324 \\
(-3.34)\end{array}$ & $\begin{array}{l}-1.190 \\
(-3.08)\end{array}$ & $\begin{array}{c}-1.199 \\
(-3.10)\end{array}$ \\
\hline Half-time college student & $\begin{array}{l}-1.134 \\
(-1.77)\end{array}$ & $\begin{array}{c}-1.132 \\
(-1.76)\end{array}$ & $\begin{array}{r}-1.182 \\
(-1.86) \\
\end{array}$ & $\begin{array}{r}-1.191 \\
(-1.88) \\
\end{array}$ \\
\hline Less than half-time college student & $\begin{array}{r}-1.045 \\
(-1.94)\end{array}$ & $\begin{array}{l}-1.037 \\
(-1.92)\end{array}$ & $\begin{array}{r}-1.057 \\
(-2.02)\end{array}$ & $\begin{array}{l}-1.075 \\
(-2.05)\end{array}$ \\
\hline Working tull-time & $\begin{array}{r}-0.503 \\
(-1.19)\end{array}$ & $\begin{array}{l}-0.532 \\
(-1.25)\end{array}$ & $\begin{array}{r}-0.363 \\
(-0.89)\end{array}$ & $\begin{array}{r}-(0.362 \\
(-0.88)\end{array}$ \\
\hline Working part-time & $\begin{array}{r}-0.193 \\
(-0.47) \\
\end{array}$ & $\begin{array}{r}-0.212 \\
(-0.52)\end{array}$ & $\begin{array}{c}-0.158 \\
(-0.39)\end{array}$ & $\begin{array}{c}-0.164 \\
(-0.41)\end{array}$ \\
\hline
\end{tabular}


Table 3 (continued)

\begin{tabular}{|c|c|c|c|c|}
\hline Unemployed & $\begin{array}{r}0.030 \\
(0.04)\end{array}$ & $\begin{array}{r}0.020 \\
(0.03)\end{array}$ & $\begin{array}{r}0.095 \\
(0.13)\end{array}$ & $\begin{array}{r}0.084 \\
(0.12)\end{array}$ \\
\hline Infrequent religious participation & $\begin{array}{r}0.019 \\
(0.06)\end{array}$ & $\begin{array}{r}0.013 \\
(0.04)\end{array}$ & $\begin{array}{r}0.032 \\
(0.10)\end{array}$ & $\begin{array}{r}0.045 \\
(0.14)\end{array}$ \\
\hline Frequent religious participation & $\begin{array}{c}-0.970 \\
(-2.24)\end{array}$ & $\begin{array}{l}-1.007 \\
(-2.34)\end{array}$ & $\begin{array}{c}-0.727 \\
(-1.85)\end{array}$ & $\begin{array}{l}-0.711 \\
(-1.81)\end{array}$ \\
\hline Married & $\begin{array}{c}-2.649 \\
(-6.04)\end{array}$ & $\begin{array}{l}-2.658 \\
(-6.05)\end{array}$ & $\begin{array}{l}-2.413 \\
(-5.85)\end{array}$ & $\begin{array}{c}-2.414 \\
(-5.85)\end{array}$ \\
\hline Engaged & $\begin{array}{r}-1.598 \\
(-3.42)\end{array}$ & $\begin{array}{c}-1.588 \\
(-3.39)\end{array}$ & $\begin{array}{c}-1.478 \\
(-3.26)\end{array}$ & $\begin{array}{l}-1.474 \\
(-3.25)\end{array}$ \\
\hline Separated or divorced & $\begin{array}{c}-0.371 \\
(-0.50)\end{array}$ & $\begin{array}{r}-0.383 \\
(-0.51)\end{array}$ & $\begin{array}{r}-0.282 \\
(-0.39)\end{array}$ & $\begin{array}{r}-0.266 \\
(-0.36)\end{array}$ \\
\hline Number of children & $\begin{array}{c}-0.128 \\
(-0.39)\end{array}$ & $\begin{array}{c}-0.147 \\
(-0.44)\end{array}$ & $\begin{array}{c}-0.098 \\
(-0.31)\end{array}$ & $\begin{array}{c}-0.094 \\
(-0.29)\end{array}$ \\
\hline 1978 & $\begin{array}{r}2.731 \\
(1.87)\end{array}$ & $\begin{array}{r}2.819 \\
(1.88)\end{array}$ & $\begin{array}{r}1.748 \\
(1.30)\end{array}$ & $\begin{array}{r}1.719 \\
(1.25)\end{array}$ \\
\hline 1979 & $\begin{array}{r}2.349 \\
(1.79)\end{array}$ & $\begin{array}{r}2.423 \\
(1.80)\end{array}$ & $\begin{array}{r}1.337 \\
(1.14)\end{array}$ & $\begin{array}{r}1.311 \\
(1.09)\end{array}$ \\
\hline 1980 & $\begin{array}{r}2.592 \\
(2.60)\end{array}$ & $\begin{array}{c}2.608 \\
(2.55)\end{array}$ & $\begin{array}{r}1.811 \\
(2.05)\end{array}$ & $\begin{array}{r}1.783 \\
(1.97)\end{array}$ \\
\hline$\overline{1981}$ & $\begin{array}{r}2.940 \\
(3.42)\end{array}$ & $\begin{array}{r}2.985 \\
(3.42)\end{array}$ & $\begin{array}{r}2.328 \\
(2.98)\end{array}$ & $\begin{array}{r}2.304 \\
(2.90)\end{array}$ \\
\hline 1982 & $\begin{array}{r}1.851 \\
(2.45)\end{array}$ & $\begin{array}{r}1.841 \\
(2.39)\end{array}$ & $\begin{array}{r}1.311 \\
(1.90)\end{array}$ & $\begin{array}{r}1.263 \\
(1.80)\end{array}$ \\
\hline 1983 & $\begin{array}{r}0.557 \\
(0.78)\end{array}$ & $\begin{array}{r}0.597 \\
(0.83)\end{array}$ & $\begin{array}{l}-0.050 \\
(-0.08)\end{array}$ & $\begin{array}{l}-0.076 \\
(-0.12)\end{array}$ \\
\hline 1984 & $\begin{array}{r}1.360 \\
(2.30)\end{array}$ & $\begin{array}{r}1.337 \\
(2.25)\end{array}$ & $\begin{array}{r}0.997 \\
(1.81)\end{array}$ & $\begin{array}{r}0.955 \\
(1.73)\end{array}$ \\
\hline 1985 & $\begin{array}{r}1.939 \\
(3.47)\end{array}$ & $\begin{array}{r}1.897 \\
(3.36)\end{array}$ & $\begin{array}{r}1.784 \\
(3.28)\end{array}$ & $\begin{array}{r}1.747 \\
(3.20)\end{array}$ \\
\hline 1986 & $\begin{array}{r}0.535 \\
(1.08)\end{array}$ & $\begin{array}{r}0.516 \\
(1.03)\end{array}$ & $\begin{array}{r}0.473 \\
(0.97)\end{array}$ & $\begin{array}{r}0.463 \\
(0.95)\end{array}$ \\
\hline R-squared & 0.045 & 0.045 & 0.240 & 0.240 \\
\hline Hausman chi-squared & 3.227 & 4.077 & & \\
\hline $\mathrm{N}$ & 8.926 & 8.926 & 8.926 & 8.926 \\
\hline
\end{tabular}

Vote: Asymptotic t-statistics in parentheses, and intercepts not shown 
Table 4

Price Elasiticities of Demand

\begin{tabular}{||l|l|l|l|l||}
\hline \multirow{2}{*}{ Panel A: Participation } & \multicolumn{2}{|c|}{$\begin{array}{c}\text { Two-Stage Least } \\
\text { Squares }\end{array}$} & \multicolumn{2}{c|}{$\begin{array}{c}\text { Ordinary Least } \\
\text { Squares }\end{array}$} \\
\cline { 2 - 5 } & $\mathbf{1}$ & $\mathbf{2}$ & $\mathbf{2}$ & $\mathbf{( 3 )}$ \\
\hline Long run & -1.560 & -1.400 & -1.378 & -1.264 \\
\hline Short run & -0.798 & -0.716 & -0.735 & -0.675 \\
\hline Temporary current & -0.335 & -0.304 & -0.365 & -0.336 \\
\hline Temporary past & -0.164 & -0.149 & -0.170 & -0.156 \\
\hline Temporary future & -0.194 & -0.175 & -0.184 & -0.169 \\
\hline Panel B: Frequency Given & & & & \\
Positive Participation & & & & \\
\hline Long run & -0.485 & -0.452 & -0.492 & -0.443 \\
\hline Short run & -0.358 & -0.348 & -0.319 & -0.288 \\
\hline Temporary current & -0.273 & -0.265 & -0.211 & -0.191 \\
\hline Temporary past & -0.071 & -0.061 & -0.074 & -0.067 \\
\hline Temporary future & -0.065 & -0.063 & -0.071 & -0.064 \\
\hline Panel C: Unconditional ${ }^{\mathrm{a}}$ & & & & \\
\hline Long run & -2.044 & -1.852 & -1.870 & -1.707 \\
\hline Short run & -1.156 & -1.064 & -1.054 & -0.963 \\
\hline Temporary current & -0.608 & -0.570 & -0.576 & -0.526 \\
\hline Temporary past & -0.235 & -0.210 & -0.244 & -0.223 \\
\hline Temporary future & -0.259 & -0.238 & -0.255 & -0.233 \\
\hline \hline
\end{tabular}

\footnotetext{
${ }^{2}$ Unconditional long-run elasticity, for example, equals the sum of long-run participation elasticity and longrun frequency elasticity.
} 
Table 5

Price and Consumption Coefficients, Year and Age Variables Omitted ${ }^{\mathrm{a}}$

\begin{tabular}{|c|c|c|}
\hline & $\begin{array}{c}\text { Two-Stage Least } \\
\text { Squares }\end{array}$ & $\begin{array}{l}\text { Ordinary Least } \\
\text { Squares }\end{array}$ \\
\hline Panel A: Participation & $(1)$ & $(2)$ \\
\hline 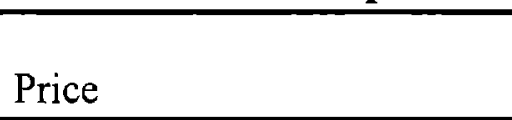 & $\begin{array}{l}-0.0001 \\
(-3.29)\end{array}$ & $\begin{array}{l}-0.0001 \\
(-4.70)\end{array}$ \\
\hline Past participation & $\begin{array}{r}0.413 \\
(11.88) \\
\end{array}$ & $\begin{array}{r}0.379 \\
(86.55)\end{array}$ \\
\hline Future participation & $\begin{array}{r}0.439 \\
(13.99) \\
\end{array}$ & $\begin{array}{r}0.410 \\
(96.27)\end{array}$ \\
\hline R-squared & 0.163 & 0.484 \\
\hline Hausman chi-squared & 5.604 & \\
\hline $\mathrm{N}$ & 38,885 & 38,885 \\
\hline \multicolumn{3}{|l|}{ Elasticities } \\
\hline Long run & -0.633 & -0.493 \\
\hline Short run & -0.290 & -0.261 \\
\hline Temporary current & -0.123 & -0.129 \\
\hline \multicolumn{3}{|c|}{$\begin{array}{l}\text { Panel B: Frequency Given } \\
\text { Positive Participation }\end{array}$} \\
\hline Price & $\begin{array}{r}-0.005 \\
(-3.51)\end{array}$ & $\begin{array}{r}-0.003 \\
(-3.33)\end{array}$ \\
\hline Past frequency & $\begin{array}{r}0.189 \\
(2.80) \\
\end{array}$ & $\begin{array}{r}0.311 \\
(29.67) \\
\end{array}$ \\
\hline Future frequency & $\begin{array}{c}0.191 \\
(3.21)\end{array}$ & $\begin{array}{r}0.303 \\
(32.16)\end{array}$ \\
\hline R-squared & 0.035 & 0.236 \\
\hline Hausman chi-squared & 8.135 & \\
\hline $\mathrm{N}$ & 8,926 & 8,926 \\
\hline \multicolumn{3}{|l|}{ Elasticities } \\
\hline Long run & -0.245 & -0.278 \\
\hline Short run & -0.197 & -0.181 \\
\hline Temporary current & -0.158 & -0.120 \\
\hline
\end{tabular}

\footnotetext{
${ }^{a}$ Drinking age and marijuana decriminalization measures omitted from both models. Asymptotic tstatistics in parentheses.
} 
Table 6

Price and Consumption Coefficients, Two-Stage Least Squares Fixed-Effects Models ${ }^{\mathrm{a}}$

\begin{tabular}{||l|c|c||}
\hline Panel A: Participation & $(\mathbf{1})$ & $\mathbf{( 2 )}$ \\
\hline Price & -0.0002 & -0.0002 \\
\hline & $(-2.88)$ & $(-2.87)$ \\
\hline Past participation & 0.207 & 0.210 \\
\hline & $(3.60)$ & $(3.68)$ \\
\hline Future participation & 0.298 & $(4.05)$ \\
\hline R-squared & $(4.23)$ & 0.023 \\
\hline Hausman chi-squared & 0.022 & 94.542 \\
\hline N & 96.031 & 35,494 \\
\hline & 35,494 & \\
\hline Elasticities & & -0.536 \\
\hline Long run & & -0.416 \\
\hline Short run & -0.550 & -0.290 \\
\hline Temporary current & -0.428 & \\
\hline & -0.291 & \\
Panel B: Frequency Given & & -0.004 \\
Positive Participation & & $(-0.76)$ \\
\hline Price & & 0.250 \\
\hline Past frequency & -0.004 & $(2.07)$ \\
\hline Future frequency & $(-0.66)$ & 0.256 \\
\hline R-squared & 0.345 & $(2.64)$ \\
\hline Hausman chi-squared & $(2.51)$ & 0.029 \\
\hline N & 0.289 & 49.547 \\
\hline & $(2.82)$ & 7,763 \\
\hline Elasticities & 0.027 & -0.141 \\
\hline Long run & 50.636 & -0.265 \\
\hline Short run & 7,763 & \\
\hline Temporary current & & \\
\hline
\end{tabular}

\footnotetext{
${ }^{a}$ Drinking age and marijuana decriminalization measures omitted from the first model and included in the second model. Asymptotic t-statistics in parentheses.
} 